Turkey husbandry and use in Oaxaca, Mexico: a contextual study of turkey remains and SEM analysis of eggshell from the Mitla Fortress

Heather A. Lapham ${ }^{\mathrm{a}, *}$, Gary M. Feinman ${ }^{\mathrm{b}}$, and Linda M. Nicholas ${ }^{\mathrm{b}}$ 


\begin{abstract}
Recent excavations of two domestic residences at the Mitla Fortress, dating to the Classic to Early Postclassic period (ca. AD 300-1200), have uncovered the remains of juvenile and adult turkeys (both hens and toms), several whole eggs, and numerous eggshell fragments in domestic refuse and ritual offering contexts. Holistically, this is the clearest and most comprehensive evidence to date for turkey domestication in the Central Valleys of Oaxaca, Mexico. Juvenile turkeys range in age, from recently hatched poults to young juvenile birds. Medullary bone, which only forms in female birds before and during the egg-laying cycle, indicates the presence of at least one egg-laying hen. Scanning electron microscope (SEM) images of the eggshell reveals both unhatched and hatched eggs from a range of incubation stages, from unfertilized or newly fertilized eggs to eggs nearing the termination of embryogenesis to hatched poults. We present these new data and explore turkey husbandry, consumption, and use by two residential households at the Mitla Fortress.
\end{abstract}

\title{
KEYWORDS
}

turkey, domestication, diet, ritual, scanning electron microscopy, SEM, Mitla, Mesoamerica 
Recent excavations at the Mitla Fortress have produced the earliest and best evidence to date of turkey domestication among the ancient Zapotecs, who resided for millennia in the Valley of Oaxaca in the southern highlands of Mexico. When and where turkeys were first domesticated in Mexico is uncertain, both for the Valley of Oaxaca and neighboring regions as well as in Mesoamerica as a whole (Thornton and Emery, 2015; Thornton et al., 2012). Moreover, questions abound in the literature about how best to define, detect, and explain domestication in the archaeological record (Clutton-Brock, 2012; Colledge et al., 2013; Price and Bar-Yosef, 2011; Serpell, 1996; Smith, 1995; Vigne et al., 2005; Zeder, 2015; Zeder et al., 2006). The most holistic answers are those that consider the specific cultural, environmental, and biological contexts that contribute to the evolving relationship between people and the targeted animal or plant population (Zeder, 2006). Here, we present multiple lines of evidence that turkeys were intensively raised and bred for meat and other by-products (eggs, bones, feathers, etc.) and for ritual use in the Valley of Oaxaca at least as early as the middle of the Classic period (ca. AD 400-600). In the zooarchaeological assemblage from the Mitla Fortress we have identified an unusually high proportion of turkey skeletal remains from juvenile and adult birds (both hens and toms) along with whole eggs and numerous eggshell fragments. Both unhatched and hatched eggs are present, and they represent a range of incubation stages from unfertilized or newly fertilized eggs to partially developed eggs to hatched poults. We examine turkey raising, consumption, and use at the Mitla Fortress, and explore how the availability of a new domesticate may have impacted meat diet and household economies at this settlement and elsewhere in the region.

Three subspecies of wild turkey (Meleagris gallopavo) are found in Mexico. Gould's 
turkey (M. g. mexicana) and the Rio Grande turkey (M. g. intermedia) inhabit northern and central Mexico. The South Mexican turkey (M. g. gallopavo) occupies parts of central and southern Mexico north of Oaxaca (Corona-M., 2002; Schorger, 1966:48-49), although its range is based largely on published references, not collected specimens (see Schorger, 1966:figure 8). In addition to wild turkey, the smaller ocellated turkey $(M$. ocellata) inhabits the Yucatán Peninsula in Mexico and parts of northern Belize and northern Guatemala (Howell and Webb, 1995: 226; Steadman et al., 1979). Although ocellated turkeys may have been tamed and captive raised at some Maya settlements (Hamblin, 1984:93; Masson and Peraza Lope, 2013; Thornton et al., this volume), it was subspecies of wild turkey that were domesticated in certain regions of North America. Recent aDNA studies have identified the South Mexican turkey as the wild progenitor of some modern domestic turkey breeds (Monteagudo et al., 2013). The genetic signatures of turkeys from archaeological sites in the American Southwest ruled out the South Mexican turkey as their progenitor however, suggesting at least two independent domestication events had taken place in North America (Speller at al., 2010).

Turkey husbandry is common today in rural highland and coastal regions of Oaxaca, with turkeys raised mainly in semi-grazing conditions by backyard producers who sell their birds at local and regional markets (Figure 1) (Camacho-Escobar et al., 2008b; Camacho-Escobar et al., 2014; Mallia, 1998). Most producers are woman who raise and sell turkeys to acquire income while simultaneously maintaining a household and engaging in other craft activities (ÁngelHernández et al., 2014). In backyard husbandry, turkeys are adaptable birds that thrive on a variety of different diets, from kitchen waste to cracked corn, fresh grass, and commercial feed (Pérez-Lara et al., 2013). Turkeys raised in larger areas with ample trees and shrubs feed 
themselves by foraging the brush for insects and vegetation, freeing the producers from the need to provide supplemental feed (Hurst, 1992; Mallia, 1998). These backyard turkeys are self-reliant and robust birds that tolerate a range of environmental conditions, including hot, arid climates (BOSTID, 1991:157-165). They produce high numbers of offspring compared to other farmraised livestock (such as goats, pigs, and cattle), and they grow quickly into a source of highquality meat (BOSTID, 1991:157-165; Hulet et al., 2004). In addition, the turkeys raised by backyard producers in Mexico today are more disease resistant than modern commercial varieties because they have developed a natural resistance to certain bacteria that inflict high deaths among commercially raised birds (Camacho-Escobar et al., 2008a; Davison, 2013).

Turkeys are raised to eat, to give as gifts, and for use in rituals among the Zapotec (Arfman, 2008; Beals, 1970; Diskin, 1979; Parsons, 1936:35, 49, 298) and other nearby groups such as the Mixe (Beals, 1945:59, 85-94, 108; Lipp, 1991:2, 83, 108). Turkeys and turkey eggs are appropriate and expected gifts in a variety of celebratory occasions, from birthdays to baptisms, weddings, and religious festivals (Beals, 1970; Diskin, 1979; Parsons, 1936:98, 108, 111, 196-197; Starkman, 2014). In Oaxaca, the market demand for and price of turkeys fluctuates throughout the year, with peak sales occurring during seasons of high ritual activity (Beals, 1970). Reciprocal exchanges and ritual gifting, obligatory traditions that underlie the socioeconomic structure of many Oaxacan communities, often include turkeys (Beals, 1970; Cohen, 1999; Cook, 2014:236-237; Parsons, 1936:560-561). Many occasions call for the gifted bird to be appraised based on maturity and weight so that a reciprocal gift of equal value can be made at a future event (Beals, 1970; Diskin, 1979; Parsons, 1936:196-197). Turkey eggs are larger, and thus a more valuable gift, than eggs from farm-raised and commercially raised 
chickens (Diskin, 1979). In the twentieth century, turkeys were sacrificed during agricultural and calendrical rites. Turkey blood was used to petition to the gods for a prosperous year, a successful birth and a newborn baby's health, to reverse the fate of child born on a bad day, and nourish the earth during times of drought, among many other things (Beals, 1945:26-27, 53, 8594; Köng and Sellen, 2015:figure 15.8; Lipp, 1991:78-81, 88-91, 106, 117-121, 140-141; Parsons, 1936:216, 237, 294, 301).

Many different uses of domestic turkeys are described in the fifteenth through seventeenth centuries that are similar to modern uses. Turkeys were bred and sold at market for food and other purposes (Horcasitas and George, 1955). In colonial Oaxaca, peasant families periodically gifted turkeys to village nobles (Horcasitas and George, 1955; Starr, 1987). They were a common animal sacrificed during rituals to cure illnesses, to protect against harm, to secure good health and rich harvests, to bless a new home, and in various other rites surrounding marriage, birth, and death (Arfman, 2008:118-121, 130; Lind, 2015: 217, 219, 223-226). The archaeological record of Zapotec religion provides ample evidence that similar sorts of rituals and animal sacrifices extended far back in time (Feinman et al., 2008; Lapham et al., 2013b; Lind and Urcid, 2010:283; Marcus, 1978). Their iridescent feathers made attractive additions to clothing and ceremonial accouterments (for references to feather artisans, see Sahagún, 1959:8497). Turkey parts had medicinal importance too in some parts of Mexico. Meat, fat, bile, caruncles, and gizzard stones were used in a variety of preparations to increase saliva flow, reduce excessive heat, lessen epileptic seizures, weaken arthritic pain, and to aid in aspects of childbirth and the dying process (Corona-M., 2008).

The earliest turkey remains were seemingly brought to the Valley of Oaxaca from areas 
farther north that sustained wild populations. Four turkey bones have been found in Early Formative deposits dated ca. 1400-800 BC at a large civic ceremonial center in the northern arm of the valley (Flannery and Marcus, 2005:188, 245, 251). The procurement of imported wild turkey evidently occurred infrequently, as other smaller Formative period sites have not yielded turkey (Drennan, 1976:appendix VIII; Whalen, 1981:appendix V; Winter, 1972:159-168), nor have earlier Archaic period sites (Flannery and Wheeler, 1986). Turkey first appears in the valley in small frequencies at the onset of the Early Classic period (ca. AD 200-500) (Lapham et al., 2013b), after which it occurs regularly in zooarchaeological assemblages from Classic and Postclassic sites in the valley (Faulseit, 2013:231; Feinman et al., 2008; Haller et al., 2006; Lapham et al., 2013b; Lind and Urcid, 2010:283; Martínez-Lira and Corona-M., this volume; Middleton et al., 2002; Paddock, 1983). Wild and later domestic turkey also have been identified northwest of the valley in the mountainous Mixtec region in Formative and Postclassic deposits (Forde, 2015; Lapham et al., 2013a; Pérez, 2003) and in late Postclassic and Colonial contexts near the Pacific Coast in the Isthmus of Tehuantepec region (Zeitlan, 2015).

The oldest purported domestic turkey in southern Mexico has been identified about 250 km north of the Mitla Fortress in the Tehuacán Valley, Puebla (a state that borders Oaxaca to the northwest), in a Terminal Formative period (Early Palo Blanco phase) deposit dated ca. AD 180 (Flannery, 1967:155, 163, 175). Excavations at Coxcatlan Cave yielded one turkey bone in an assemblage containing fewer than 160 identified specimens (Flannery, 1967:table 16). The classification of this bone as domestic turkey (versus wild turkey) was suggested based on the observation that wild turkey never inhabited regions as far south as the Tehuacán Valley (Flannery, 1967:155) along with the absence of turkey remains in earlier deposits and their 
presence in later contexts at nearby sites (Flannery 1967:tables 16-20). Although the lone turkey bone from Coxcatlan Cave may represent a domestic bird, the possibility of imported wild turkey cannot be dismissed.

Farther north, in regions within the wild turkey range, fifteenth century Spanish accounts report turkeys being raised in quantity near the Aztec capital Tenochtitlán in the Valley of Mexico (about $450 \mathrm{~km}$ north of Oaxaca) and likely elsewhere in Mesoamerica (Schorger, 1966:10-11). Archaeological findings in central Mexico corroborate turkey remains in refuse and ritual contexts as far back as the Formative period up through the sixteenth century (CoronaM., 1997; Manin et al., this volume; Valadez et al., 2001; Valadez and Rodríguez, 2014). In northern Mexico and the American Southwest, domestic turkeys are found at human habitation sites by around AD 500, with more evidence appearing after AD 900 (Munro, 2011). Genetic data from archaeological sites in the southwestern United States dated between AD 600-1800 identified a unique breed of domestic turkey that resulted from intensive selection and breeding practices (Speller at al., 2010). Archaeological signatures of turkey domestication in these more northern regions include the presence of eggshell, juvenile skeletal remains, broken and healed bones, feathers, gizzard stones, turkey droppings, and retaining enclosures (Breitburg, 1988; Fothergill, this volume; Munro, 2011), with variable husbandry practices apparent throughout the Southwest (Badenhorst and Driver, 2009; Conrad et al., this volume; Jones et al., this volume; Rawlings and Driver, 2010).

\section{THE MITLA FORTRESS}

The Mitla Fortress is located on a steep, freestanding hill that juts up from the 
surrounding floodplain near Mitla in the eastern arm of the Valley of Oaxaca (Figure 2). The settlement, occupied from roughly AD 300 to 1400, is estimated to have been occupied by more than a thousand people during the Classic period, with habitation continuing into the Postclassic (Feinman and Nicholas, 2004:47, 51), when the hilltop settlement was incorporated into the much larger Mitla site. The animal remains we discuss here come from residential deposits associated with two adjacent commoner households (Terraces 56 and 57) (Figure 3). These two households along with a third lower status residence (Terrace 256) located in the eastern sector of the site are the only terraces excavated to date at the Mitla Fortress.

Excavated in 2009 and 2010, the domestic complexes on Terraces 56 and 57 each contain a central patio surrounded by adjacent rooms demarcated by adobe and stone foundations and walls. The residential components span several hundred years, beginning in the Early-Mid Classic period about AD 300-500 and continuing until roughly AD 1000-1100 in the Early Postclassic period. Both households worked obsidian and produced maguey fiber, among other domestic activities, and buried their dead under house and patio floors. Located down slope from the civic-ceremonial center located at hill's apex, the two adjacent residences may have housed the head of a barrio or neighborhood within the larger Mitla Fortress community (Feinman et al., 2010).

\section{TURKEY REMAINS ON TERRACES 56 AND 57}

In recent research on animal economies in the Oaxaca and Ejutla Valleys we have identified site-specific patterns of animal use at different communities across the region (Lapham et al., 2013b). Each settlement we studied, including the Mitla Fortress, exhibits a unique 
zooarchaeological signature that reflects slightly different animal specializations and meat-based diets. At the Mitla Fortress, the residents of Terraces 56 and 57 relied on five main taxa to fulfill their meat-based subsistence needs — white-tailed deer (Odocoileus virginianus), domestic dog (Canis familiaris), jackrabbits (Lepus spp.), cottontail rabbits (Sylvilagus spp.), and turkey (Meleagris gallopavo). Dogs and, we argue, turkeys were raised and kept by the terrace residents, whereas deer and rabbits were hunted and trapped in their wild habitats, although not necessarily by the families who lived on Terraces 56 and 57 .

A wider suite of animals was utilized by the two households for food and other purposes (Table 1). These wild animals were hunted, trapped, and caught in local, nearby, and distant habitats. Armadillo and nonlocal river turtle were imported to the valley from tropical habitats closer to the coast (Goodwin, 1969; Smith and Smith, 1979). Some animal resources likely were procured by the residents themselves; others may have been acquired as gifts, through trade, and in markets.

\section{Turkeys in Domestic Refuse}

On Terraces 56 and 57, turkey is second only to dog in terms of relative dietary importance based on the number of identified specimens (NISP) of animal remains from refuse contexts that could be assigned to an occupation period (Table 1). NISP is a count of the number of bones and fragments identified per taxa. We base our comparisons on NISP rather than other quantitative units because comparable data have been collected and published for other sites in the Valley of Oaxaca. Dog is present in slightly higher proportions in the assemblage, whereas rabbits and deer are found in lower proportions. The majority $(60 \%)$ of the faunal refuse from 
Terraces 56 and 57 is represented by domestic taxa (dog and turkey). The turkey assemblage contains both juvenile and adult birds, with a wide range of skeletal elements identified (Table 2). Differences in cortical bone development and skeletal element size indicate the presence of three different ages of juvenile turkeys: newly or recently hatched poults, very young birds, and young birds. These specimens are comparable to McKusick's (1986:19) juvenile age stage.

Adult turkeys, both hens (females) and toms (males), are present. A left femur from the east room of the residence on Terrace 57 contains medullary bone (Figure 4a-b). Medullary bone only forms in the marrow cavity of certain long bones of female birds, beginning slightly before the egg-laying cycle and continuing throughout its duration. It serves as a source of calcium for the formation of eggshells, and its growth and subsequent resorption when egg laying ceases is regulated by hormones (Cogburn et al., 2015; Whitehead, 2004). Toms are identified by the presence of a tarsal spur, a sharp projection that protrudes from the rear of the lower leg (the tarsometatarsus). Toms use these spike-like protrusions when they spar with other males to establish the pecking order. Hens, in contrast, rarely have spurs (Pelham, 1992; Schorger, 1966).

Eggs and eggshell were surprisingly common, with at least eight whole eggs, three partial eggs (represented by 250 eggshell fragments), and more than 70 miscellaneous eggshell fragments identified in 32 different contexts (both domestic and ritual) in the two residences. Only one of the eight whole eggs came from domestic refuse in an exterior area of Terrace 56 near the retention wall. To minimize the possible over-representation of turkey remains, we typically counted eggshell fragments from one context as one NISP (the total number of fragments are noted in the comments field of the database).

For comparative purposes, data are presented from the only other terrace studied to date 
at the Mitla Fortress-Terrace 276, excavated in 2011. The residents of Terrace 276 relied more on wild animals and less on domestic species for the meat portion of their diet, indicating a household economy based on greater participation in hunting and gathering. Turkey was outnumbered by dog, rabbits, and deer so that the overall assemblage is more evenly distributed among the primary taxa (Table 3 ). Unlike the two western terraces, Terrace 276 contains mostly adult turkeys.

From a regional perspective, turkey is found in greater numbers and higher frequencies at the Mitla Fortress compared to other Classic to Early Postclassic period settlements in the Central Valleys of Oaxaca. Turkey is significantly less common at El Palmillo and Lambityeco and is rare at Ejutla (Table 4). Terraces 56 and 57 at the Mitla Fortress contain nearly five times as much turkey as these other broadly contemporaneous sites. In each settlement, the production of craft goods, agricultural products, and animals and animal by-products for consumption and market exchange occurred at the household level, with domestic units exhibiting substantial economic differentiation within their communities (Carpenter et al., 2012; Feinman and Nicholas, 2007, 2010, 2012; Lapham et al., 2013b).

\section{Modified Turkey Bone}

The residents of Terraces 56 and 57 at the Mitla Fortress also crafted tools and ornaments from turkey wing and leg bones, including a perforator made from a turkey radius and two awls made from turkey tibiotarsi, along with two pieces of manufacturing waste (both from the tibiotarsus element) (Figure 5). Awls and perforators were employed to create holes for thread, cordage, and sinew to move through materials such as woven textiles and animal hides, in 
addition to other functions. Awls are typically stouter tools with a thicker point, although awls made from bird bones are more delicate than those crafted from large mammal long bones. These tools exhibit a characteristic V-like shape, whereas perforators are straighter, more linear in appearance with a more slender profile and sharply pointed tip. The longest, straightest, and sturdiest skeletal elements are preferred; turkey tibiotarsi, in particular, meet these criteria. In addition to tools, a single bead crafted from a turkey ulna also was recovered. Two dozen plus bone tools and ornaments could be identified only to large bird. Many if not most of these items likely were produced from turkey bone, but due to high degrees of modification the fragments lack the diagnostic morphological characteristics needed for positive identifications.

Almost one quarter of the modified animal remains from Terraces 56 and 57 are tools and ornaments produced from turkey and unidentified large bird bones (Table 5). This proportion is more than double the frequency of modified bird remains on Terrace 276 (Table 5). Beyond the Mitla Fortress, modified turkey and bird remains are rare at El Palmillo and Ejutla but more common at Lambityeco (Table 5). At Lambityeco, the percentage of modified turkey remains is slightly higher than the percent of unmodified turkey remains within their respective assemblages (see Tables 4 and 5). The residents of Mound 165 at Lambityeco produced very fine beads using turkey tibiotarsi (Lapham, 2013), which in part may explain the higher frequency of modified bird in the assemblage compared to surrounding sites.

\section{Turkey Offerings}

Throughout the Valley of Oaxaca, pre-Hispanic Zapotec ritually killed animals to honor the ancestors, worship the gods, and gain the favor of various deities (Feinman et al., 2008; Lind, 
2015; Marcus, 1978). By colonial times, the decapitation of turkey hens occurred repeatedly in references to religious ceremonies performed to alleviate undesirable predicaments brought about by displeased gods (see Lind, 2015:57, 59, 62, 67, 69). At the Mitla Fortress, turkeys, along with puppies, were among the animals sacrificed. Two turkey offerings were placed within the residential complex on each terrace (Offerings 9 and 14 on Terrace 56 and Offerings 19 and 21 on Terrace 57) (Figure 6). Juvenile animals were preferred; the only exception is an adult turkey placed alongside two juvenile turkeys in a context that post-dates the residential occupation on Terrace 57 (Offering 19). Fertilized, unhatched eggs also were included in the offerings, which were laid below house floors and in exterior walls of houses.

One of the largest offerings of turkey on Terrace 56 (Offering 9) contains the remains of at least seven recently hatched poults and five whole turkey eggs placed beneath a floor at the beginning of the earliest occupation on the terrace (Figure 7). We identified more than 200 bones and bone fragments, including tiny phalanges, in the offering (Figure 8). One of the whole eggs measures $60 \mathrm{~mm}$ in height and $44 \mathrm{~mm}$ in diameter with a shell thickness of $.53 \mathrm{~mm}$. Given the variation in the size of individual elements within each postcranial element grouping, it is likely the poults in the offering came from more than one brood. Potentially, molecular analyses could be used in the future to determine if the eggs came from the same or different clutches, as microsatellite profiles of eggshell DNA will be identical among eggs from the same clutch (Egloff et al., 2009). If genetic material can be extracted successfully from the Mitla Fortress eggshells, information about sex at hatching also could be evaluated (Brown et al., 2006).

Offering 14 , also from Terrace 56, contains a very young turkey associated with the beginning of the earliest residence, similar to Offering 9. It too was placed beneath a floor, in a 
room on the east side of the complex, probably the same room as Offering 9. Eggshell fragments also were recovered along with a variety of other items from the grave (Burial 11) of an adult woman (26-34 years old) and newborn child buried in a stone cist on Terrace 56. Although it is difficult to say with certainty, these pieces of eggshell may have formed a whole egg that had been interred with the deceased.

One offering (Offering 19) in post-residential deposits on Terrace 57 contains the remains of three turkeys at three different life stages (one recently hatched poult, one young bird, and one adult bird) and one or two whole eggs. The second offering (Offering 21), from the later residential occupation, contains the remains of a recently hatched poult and at least one partial to whole egg. One human burial on Terrace 57 also yielded offerings of turkey. The grave of an older adult man (Burial 26) contains the remains of three turkeys (one recently hatched poult, one very young bird, and one young bird) and at least one partial to whole egg, along with a newborn puppy and two obsidian blades that possibly were used to sacrifice the animals.

\section{SCANNING ELECTRON MICROSCOPE ANALYSIS OF EGGSHELL FROM THE MITLA FORTRESS}

A sample of eggshell from domestic refuse and special contexts at the Mita Fortress was examined using a scanning electron microscope (SEM) to determine if the eggshell could be positively identified to turkey and to assess the developmental stage of the eggs. Avian eggshell can be distinguished among different genera and species based on differences in the internal microstructure of the shell, the cone-shaped features that comprise the mammillary layer of the egg (Keepax, 1981; Sidell, 1993). Additionally, patterned changes in the mammillary layer 
during the incubation period can be used to determine the degree of embryo development (Beacham and Durand, 2007).

The eggshells were cleaned by submersion in $20 \mathrm{~mL}$ of distilled water contained in individual glass beakers agitated in an ultrasonic bath for five minutes to remove contaminants. Each eggshell was then transferred to a labeled jar and placed into an oven set to $45^{\circ} \mathrm{C}$ to dry overnight. The clean, dry specimen was mounted on an aluminum stub using colloidal graphite with the interior eggshell facing upward following the methods outlined in Sidell (1993). The mounted eggshells were placed again in a $45^{\circ} \mathrm{C}$ oven to dry overnight, allowing the colloidal graphite to harden slightly. Next, the eggshells were sputter-coated with $500 \AA$ of gold-palladium using a Denton Desktop II Sputter Coater to make them conductive in the microscope (following Bozzola and Russel, 1999). Lastly, digital images of two randomly chosen locations on each eggshell were captured at magnifications of 250x, 500x, and 1000x with a FEI Quanta ${ }^{\mathrm{TM}} 450$ FEG and Hitachi S570 SEM at SIU's Integrated Microscopy and Graphics Expertise (IMAGE) facility.

SEM micrographs were acquired from a sample of 15 specimens from 10 contexts on Terraces 56 and 57 (Table 6). Five samples date to the earlier Surface 2 occupation during the mid Classic period (ca. AD 400-600). Nine samples date to the later Surface 1 occupation during the Late Classic period and possibly into the Early Postclassic (ca. AD 650-900/950), and one sample dates to a post-residential occupation during the Middle/Late Postclassic period (ca. AD 1200-1520).

All sampled eggshells from the Mitla Fortress are identifiable to turkey based on a comparison of the internal microstructure of the archaeological specimens with modern domestic 
turkey eggshell (Meleagris gallapavo) as pictured in Sidell (1993:39). We are confident in assigning the eggshell recovered from the Mitla Fortress to turkey based on the SEM results combined with the high frequency of turkey bones relative to other avian taxa in the general faunal assemblage, the wide range of turkey ages represented (from recently hatched poults to adult birds and ages in between), and a visual examination of the eggshell morphology in the field using 5x-20x hand-held magnifiers.

The internal microstructure of the eggshells also can be used to assess how far along the egg is in the incubation period post-fertilization. To assess the degree of embryo development of the Mitla Fortress eggshells, we compared these SEM micrographs to the results of a study by Beacham and Durand (2007). In turkeys, patterned changes in the internal, mammillary layer of the eggshell's microstructure begin about 16 days after fertilization and continue in a consistent manner throughout the duration of the incubation period, which lasts for 28-29 days. These changes result from the resorption of calcium from the shell by the developing embryo (Burley and Vadehra, 1989). For comparative purposes, Beacham and Durand (2007) identified three main categories of resorption: 1) no resorption, days zero to 16 of incubation; 2) minimal resorption, days 18 to 22 of incubation; and 3) significant resorption, days 24 of incubation to hatching.

Of the 15 eggshell fragments that we sampled, one specimen shows no resorption of the mammillary layer, one shows minimal resorption, two show minimal to significant resorption, and the remaining eleven specimens show significant resorption (Table 6). We sought to differentiate individual eggs within a subset of eggshells by sampling more than one specimen from four proveniences on Terrace 57 that had large sample sizes (ranging between ca. 50-200 
shell fragments) or multiple eggs. In each case, the patterns of cone resorption were nearly identical among fragments from the same provenience (Specimens A and B in Table 6), suggesting that if more than one egg was present in these samples they could not be distinguished from one another based on developmental stage. The Approximate Days column in Table 6 compares the Mitla Fortress specimens to the patterned progression of bone resorption observed by Beacham and Durand (2007:figure 3) on modern turkey eggshell at zero, 18, 20, 22, 24, and 26 days of incubation and hatched eggshell to further separate the archaeological eggshell grouped within the minimal and significant resorption categories.

One specimen from the north room on Terrace 57 (Bag 382, see Table 6) falls into the no resorption group. No visible changes are apparent in the mammillary cones, indicating that either the egg had not been fertilized or it was less than 16 days into the incubation period when development ceased—changes to eggshell's microstructure resulting from embryonic development begin about 16 days after fertilization (Figure 9a).

The minimal resorption category is represented by one specimen from a complete egg in Offering 9 on Terrace 56 (Bag 576). The pattern of cone resorption in the mammillary layer is minimal, similar to an egg that ceased development about six to seven days prior to hatching after being fertilized and then incubated by a hen (Figure 9b). The five unhatched eggs did not contain the remains of fetal turkeys, as one might expect based on the age of the egg and known embryonic skeletal formation stages (Maxwell, 2008). Most skeletal elements have ossified or are in the process of ossification (i.e, the transformation of cartilage to bone) between 19 to 24 days. The absence of fetal bones inside the unhatched eggs likely is due to preservation, in that the delicate, partially formed bones disintegrated over time in their moist, embryonic 
surroundings.

Two specimens from a single context straddle the minimal to significant resorption categories. These two shell fragments are from one or two whole eggs from Offering 19 on Terrace 57 (Bag 195). The degree of cone resorption compares most favorably to an egg or eggs that ceased development 22-24 days post-incubation (Figure 9c).

Most of the eggshell from Terraces 56 and 57 fall into the significant resorption group. One specimen from ashy deposits on Terrace 56 (Bag 716) displays cone resorption patterns in the beginning of the significant resorption range, most similar to an egg that ceased development between days 24 and 26 of incubation (Figure 9d). Three other specimens (Bags 706 and 246) have progressed to a slightly more advanced state, representing eggs nearing the termination of embryogenesis (Figure 9e). The remaining seven specimens from Terrace 57 (Bags 10, 301, 394, $434,440)$ show such significant cone resorption that they likely represent either hatching or hatched poults (Figure 9f).

Nearly three-quarters of the sampled eggs and eggshell fragments from the Mitla Fortress fall into the significant resorption category, and almost a third of these specimens had progressed to the hatching phase. Specimens identified as partial eggs from Offering 21 (Bag 301) and Burial 26 (Bag 440) both show degrees of mammillary cone resorption comparable to eggs that had hatched or, possibly, were in the process of hatching. The results of the SEM analysis of the eggshell from these two contexts raise the possibility that hatching eggs were selected, intentionally or unintentionally, for inclusion in ritual offerings. The hatching process begins with pipping, when the poult uses a sharp protuberance on its upper beak (called an egg tooth) to crack and eventually, over about 24 hours, break free of its shell (Healy, 1992). When in close 
proximity to the egg, chipping and vocal clicking sounds can be heard as the poult chips away as its rigid shell. There is also the possibility that the eggs from Offering 21 and Burial 26 represent late embryonic mortality, where the poult died during the pipping process. Eggs must be properly incubated (by the hen or, often in modern times, by artificial means) during pipping for poults to hatch successfully (Christensen and McCorkle, 1982; Meir et al., 1984).

In contrast to the partial (possibly whole) eggs found on Terrace 57, the three whole eggs identified archaeologically from Offering 9 (Bag 576), Offering 19 (Bag 195), and an exterior area between the two complexes all exhibit cone resorption patterns consistent with fertilized, but incompletely developed eggs.

\section{DISCUSSION}

Our study of the zooarchaeological assemblage from the Mitla Fortress has identified an unusually high proportion of turkey remains, numerous turkey eggshell fragments and several whole eggs, as well as the remains of juvenile and adult birds (both hens and toms) in domestic refuse and ritual offering contexts. At least one egg-laying hen is present, along with both unhatched and hatched eggs representing all stages of incubation. These data are robust indicators that turkeys were being raised and kept by some families in the Valley of Oaxaca as

early as the mid Classic period (ca. AD 400-600). In the households on Terraces 56 and 57 at the Mitla Fortress, turkeys were second only to domestic dog in relative importance in the meat diet. Domestic and ritual contexts contain both unhatched and hatched turkey eggs as well as the remains of juvenile and adult birds (both hens and toms), and a hen who was actively laying eggs. Three ages of juvenile turkeys are present in residential deposits: recently hatched poults, 
very young birds, and young birds. The terrace residents also crafted tools and ornaments from turkey and large bird bones (most of which are likely turkey). The ritual use of turkeys is supported by four offerings, containing mostly juvenile birds, unhatched turkey eggs, and some eggs that were either in the process of hatching or fully hatched. These data provide multiple lines of evidence that turkeys were being raised on or near the two terraces, beginning as early as the mid Classic occupation at the Mitla Fortress.

The availability of a new domesticate may have had an impact on household economies initially within the community, or at the very least within specific residential compounds, and eventually at settlements in the larger region. As turkey steadily increased over time on Terraces 56 and 57 at the Mitla Fortress, dog—-the other domesticate-remained an important source of meat. Wild hunted, trapped, and captured animals (such as deer, rabbits, and turtles) decreased somewhat as turkey became a more prominent dietary resource for these two households. By the Early Postclassic period, domestic animals formed more than two-thirds of the faunal assemblage from Terraces 56 and 57. Because dogs and now turkeys could be managed and controlled, they were much more reliable, accessible, and predictable meat sources than wild animals - important factors to consider for feeding growing numbers of people residing in less environmentally favored areas in the valley.

The Mitla Fortress is located in the driest portion of the Valley of Oaxaca, the eastern end of the Tlacolula subvalley (the eastern arm of the main valley) (Feinman and Nicholas, 2005). During the Classic period, population estimates for this portion of the valley were equivalent or greater than more fertile parts of Oaxaca with higher annual rainfall and more suitable agricultural land that produced higher crop yields (Kirkby, 1973; Nicholas, 1989). Settlements 
increased in number (Kowalewski et al., 1989) and expanded into areas considered agriculturally unproductive in eastern Tlacolula, a pattern first noted during the Late Formative period (Kirkby, 1973:133-137). Kirkby (1973:141-142) has proposed this expansion into marginal zones reflected an ability to support households and communities that specialized in economic activities beyond basic maize farming. In these sectors, certain households manufactured a wide variety of craft goods (Feinman and Nicholas, 2005, 2012) and, we would add, raised animals (including turkey) for meat and other by-products. An extensive market system likely provided the mechanism by which surplus crops and other foods grown in more fertile areas of the valley could be acquired through the trade to supplement edibles harvested from locally cultivated, drought-resistant xerophytic plants (Feinman and Nicholas, 2005, 2012; Nicholas, 1989).

We propose based on our findings at the Mitla Fortress that turkey husbandry became an important component of the household economy in communities located in peripheral environmental zones in eastern Tlacolula. Specialized production by multicrafting households was widespread in Classic Oaxaca (Feinman and Nicholas, 2010, 2012), and turkeys represented a new addition to the extensive list of goods produced for household consumption and market exchange. Turkeys contributed a readily available source of meat to the diet. They served as sacrificial animals in religious practices. Live birds, their eggs, and other by-products and raw materials (such as feathers and bone) also added a suite of items useful in market-based exchanges to acquire foodstuffs and other goods. Furthermore, turkeys are hardy birds well suited to semi-arid habitats, such as those found in the Tlacolula subvalley. With only three households excavated to date at the Mitla Fortress it is difficult to assess turkey consumption and use across the site as whole, and who may have raised turkeys within the larger settlement. Our 
current findings have identified intensive turkey husbandry at two adjacent middle class residences with evidence of less intensive turkey raising at a lower status household. What these patterns meant for the community overall remains to be seen, and will require excavations in other areas of the site.

The ritual use of turkeys at the Mitla Fortress shows some stunning similarities with historic and modern Zapotec ritual practices. At Terraces 56 and 57, there are four offerings and at least one burial that contain turkey eggs and sacrificed turkeys. The bird sacrificed is almost always either a newly-hatched poult or a very young bird. Fertilized, unhatched eggs also are included in the offerings, which are laid below house floors and in exterior walls of houses. In most offerings, eggs occur alongside juvenile birds. Turkeys were a common animal sacrificed in the late pre-Hispanic and Colonial period as well, for reasons ranging from important life events (birth, death, marriage, etc.) to healing and agricultural rites, among other things (Arfman, 2008:118-121, 130; Horcasitas and George, 1955; Lind, 2015:57, 59, 62, 67, 69, 217, 219, $223-$ 226). Sacrificed turkeys also were offered to the gods prior to building a new home and, once eaten, their bones buried below house floors (Lind, 2015:231).

Twentieth century ethnographies of the Zapotec and neighboring Mixe describe turkeys as commonly used animals for blood sacrifice rituals, and other similar activities (Beals, 1945:26-27, 53, 85-94; Köng and Sellen, 2015:figure 15.8; Lipp, 1991:78-81, 88-91, 106, $117-$ 121, 140-141; Parsons, 1936:216, 237, 294, 301). More recently, less expensive chickens have replaced turkeys as a sacrificial animal if the offering location is one where blood sacrifices can be made, which have become undesirable in some places because of their inherent messiness (Arfman, 2008:88, 139, 149). Interestingly, sacrificed birds are still buried below house floors 
(Lipp, 1991:73, 102; Parsons, 1936:27) and juvenile birds (both poults and pullets) are still used in combination with eggs in certain rituals (Lipp, 1991:83, 85-86, 89, 94-95, 102, 104, 112). Eggs are both common offerings and key elements in curing rituals (Afrman, 2008:141, 146; Barabas et al., 2005; Beals, 1945:26, 97; Lipp, 1991:74, 83, 85-86, 89, 94-95, 98, 99, 101-102, 149, 172, 175; Parsons, 1936:72, 121, 136-137). At the Mitla Fortress, we have the earliest and best evidence to date in the Valley of Oaxaca not only for turkey domestication, but also the ritual use of turkeys, which is still prevalent today. The reasons might be different, certainly the gods are different, but this practice among the Zapotec of ritually sacrificing turkeys and egg offerings shows amazing continuity over an extended period.

\section{CONCLUSIONS}

We now know that raising turkeys for subsistence, ritual offerings, and marketable goods has considerable time depth in Oaxaca, dating back 1500 years in some eastern Tlacolula communities. Based on the findings from the Mitla Fortress, there is no doubt that domesticated turkeys were present in the Valley of Oaxaca by the mid Classic period (ca. AD 400-600). At the Mitla Fortress, turkey remains in refuse contexts increased five-fold compared to other contemporaneous settlements, accounting for more than a quarter $(27 \%)$ of the faunal assemblage on Terraces 56 and 57. More than 630 turkey bones were recovered from three seasons of investigations (2009-2011) at the Mitla Fortress, along with at least 10 whole and partial eggs and nearly 100 miscellaneous eggshell fragments from all refuse and offering contexts combined on the three excavated terraces. Juvenile and adult (both hens and toms) turkeys are present, along with an egg-laying hen and unhatched and hatched turkey eggs 
(ranging from unfertilized or newly fertilized eggs to eggs nearing the termination of embryogenesis to hatched poults). Turkeys were used in rituals, and turkey bones were modified for use as tools and crafted into items of personal adornment. These data provide the earliest, unequivocal evidence that turkeys were being raised and kept by some families at the Mitla Fortress. 


\section{ACKNOWLEDGMENTS}

The authors gratefully acknowledge the National Science Foundation, the Field Museum of Natural History, and a number of private benefactors for the financial support of the pertinent fieldwork. The archaeological studies at the Mitla Fortress were enacted under permits granted by Mexico’s Instituto Nacional de Antropología e Historia and the Centro Regional de Oaxaca (INAH). We deeply appreciate the dedicated work done and the help provided by those institutions and their professional staffs over the years. Dra. Nelly Roblés García has provided invaluable assistance and support for our field studies. We also thank all of the governing authorities of San Pablo Villa de Mitla, who supported and saw the historical significance of our investigations. This research would not have been possible without the dedicated assistance of our Oaxacan and North American field and laboratory crews, to whom we are thankful for all of their dedicated work. We thank Lauren Forsythe for preparing the eggshell specimens for SEM analysis and Dr. Thomas Wake (Cotsen Institute of Archaeology, University of California, Los Angeles) for his providing his expertise in the identification of fish remains. In addition to the paper's senior author, William Middleton, Jennifer Blitz, Jennifer Clark, Mikael Haller, and Ed Maher analyzed faunal assemblages from two of the comparative sites (El Palmillo and Ejutla) mentioned in this article and we recognize and value their efforts. 


\section{REFERENCES}

Ángel-Hernández, A., Jerez-Salas, M.P., Camacho-Escobar, M.A., Vázquez-Dávila, M.A., Villegas-Aparicio, Y., Rodríguez-Ortiz, G., 2014. La mujer en la comercialización del guajolote (Melleagris gallopavo L.) en los mercados de los valles centrales de Oaxaca. Actas Iberoam. de Conserv. Anim. 4, 153-157.

Arfman, W.R., 2008. Visiting the Calvario at Mitla, Oaxaca: A Critical Look at the Continuity of a Religious Practice. Sidestone Press, Leiden, The Netherlands.

Badenhorst, S., Driver, J.C., 2009. Faunal changes in farming communities from Basketmaker II to Pueblo III (A.D. 1-1300) in the San Juan Basin of the American Southwest. J. of Archaeol. Sci. 36(9), 1832-1841.

Barabas, A.M., Winter, M., del Carmen Castillo, M., Moreno, N., 2005. La cueva del diablo: creencias y rituales de ayer y de hoy entre los Zapotecos de Mitla, Oaxaca. Revista Cuadernos del Sur 11(22), 21-33.

Beacham, E.B., Durand, S.R., 2007. Eggshell and the archaeological record: new insights into turkey husbandry in the American Southwest. J. of Archaeol. Sci. 34(10), 1610-1621.

Beals, R.L., 1945. Ethnology of the Western Mixe. University of California Press, Berkeley. 
Beals, R.L., 1970. Gifting, reciprocity, savings, and credit in peasant Oaxaca. Southwest. J. of Anthropol. 26(3), 231-241.

Board on Science and Technology for International Development (BOSTID), 1991.

Microlivestock: Little-known Small Animals with Promising Economic Future. National Academy Press, Washington, D.C.

Bozzola, J.J., Russel, L.D., 1999. Electron Microscopy, second ed. Jones and Bartlett Publishers, Sudbury, Mass.

Breitburg, E., 1988. Prehistoric New World turkey domestication: origins, developments, and consequences. Unpublished Ph.D. dissertation, Department of Anthropology, Southern Illinois University, Carbondale.

Brown, A.D., Brunjes, J.H., Phillips, R.S., Ballard, W.B., Wallace, M.C., Baker, R.J., 2006 Eggshell Remains as a Non-invasive Source of Genetic Material in Wild Turkeys (Meleagris gallopavo). Occasional Papers 257, Museum of Texas Tech University, Lubbock.

Burley, R.W., Vadehra, D.V., 1989. The Avian Egg: Chemistry and Biology. John Wiley and Sons, Inc., N. Y.

Camacho-Escobar, M.A., Arroyo-Ledezma, J., Ramirez-Cancino, L., 2008a. Diseases of 
backyard turkeys in the Mexican tropics. Ann. of the N. Y. Acad. of Sci. 1149, 368-370.

Camacho-Escobar, M.A., Hernandez-Sanchez, V., Ramirez-Cancino, L., Sánchez-Bernal, E.I., Arroyo-Ledezma, J., 2008b. Characterization of backyard guajolotes (Meleagris gallopavo gallopavo) in tropical zones of Mexico. Livest. Res. for Rural Dev. 20(4), Article 50. http://www.lrrd.org/lrrd20/4/cama20050.htm

Camacho-Escobar, M.A., Jerez-Salas, M.P., Vásquez-Dávila, M.A., Ávila-Serrano, N.Y., Sánchez-Bernal, E.I., Arroyo-Ledezma, J., 2014. Venta tradicional del guajolote nativo (Meleagris gallopavo) en el sur de México. Actas Iberoam. de Conserv. Anim. 4, 164-166.

Carpenter, L.B., Feinman, G.M., Nicholas, L.M., 2012. Spindle whorls from El Palmillo: economic implications. Lat. Am. Antiq. 23(4), 381-400.

Christensen, V.L., McCorkle, F.M., 1982. Turkey egg weight losses and embryonic mortality during incubation. Poultry Sci. 61, 1209-1213.

Cogburn, L.A., Burnside, J., Scanes, C.G., 2015. Physiology of growth and development, in: Scanes, C.G. (Ed.), Sturkie's Avian Physiology, sixth ed. Academic Press, N. Y., pp. 635-656.

Cohen, J.H., 1999. Cooperation and Community: Economy and Society in Oaxaca. University of Texas Press, Austin, Tex. 
Clutton-Brock, J., 2012. Animals as Domesticates. Michigan State University Press, East Lansing.

Colledge, S., Conolly, J., Dobney, K., Manning, K., Shennan, S. (Eds.), 2013. Origins and Spread of Domestic Animals in Southwest Asia and Europe. Left Coast Press, Walnut Creek, Calif.

Conrad, C., Jones, E.L., Newsome, S.D., Schwartz, D.W., 2016. Eggshell, bone isotopes and turkey husbandry at Arroyo Hondo Pueblo. J. of Archaeol. Sci.: Reports, THIS VOLUME.

Cook, S., 2014. Land, Livelihood, and Civility in Southern Mexico: Oaxaca Valley Communities in History. University of Texas Press, Austin.

Corona-M., E., 1997. Avian resources at a Mexican site at the time of the Spanish conquest. Int. J. of Osteoarchaeol. 7, 321-325.

Corona-M., E., 2002. The Pleistocene bird record of México. Acta Zool. Crac. 45, 293-306.

Corona-M., E., 2008. Las aves como recurso curativo en el Mexico antiguo y sus posibles evidencias en la arqueozoologia. Archaeobios 2(1), 11-18. 
Davison, S., 2013 Pullorum Disease in Poultry, in: The Merck Veterinary Manual [online]. Available at:

http://www.merckvetmanual.com/mvm/poultry/salmonelloses/pullorum_disease_in_poultry.htm. Accessed 12 Sept 2015.

Diskin, M., 1979. The peasant family archive: sources for an ethnohistory of the present. Ethnohist. 26(3), 209-229.

Drennan, R.D., 1976. Prehistory and Human Ecology of the Valley of Oaxaca, Vol. 4: Fábrica San José and Middle Formative Society in the Valley of Oaxaca. Museum of Anthropology Memoirs No. 8, University of Michigan, Ann Arbor.

Egloff, C. Labrosse, A., Hebert, C., Crump, D., 2009. A nondestructive method for obtaining maternal DNA from avian eggshells and its application to embryonic viability determination in herring gulls (Larus argentatus). Mol. Ecol. Resour. 9, 19-27.

Faulseit, R.K., 2013. Cerro Danush: Excavations at a Hilltop Community in the Eastern Valley of Oaxaca. Museum of Anthropology Memoirs No. 54, University of Michigan, Ann Arbor.

Feinman, G.M., Nicholas, L.M., 2004. Hilltop Terrace Sites of Oaxaca, Mexico: Intensive Surface Survey at Guirún, El Palmillo and the Mitla Fortress. Fieldiana, Anthropology, New Series No. 37. The Field Museum of Natural History, Chic. 
Feinman, G.M., Nicholas, L.M., 2005. More than alluvial land and water: the late pre-Hispanic emergence of eastern Tlacolula, Oaxaca, Mexico, in: Blanton, R.E. (Ed.), Settlement, Subsistence, and Social Complexity: Essays Honoring the Legacy of Jeffrey R. Parsons. Cotsen Institute of Archaeology, University of California, Los Angeles, pp. 229-259.

Feinman, G.M., Nicholas, L.M., 2007. Craft production in Classic period Oaxaca: implications for Monte Albán's political economy, in Shimada, I. (Ed.), Craft Production in Multicraft and Producer Perspectives. University of Utah Press, Salt Lake City, pp. 97-119.

Feinman, G.M., Nicholas, L.M., 2010. A multiscaler perspective on market exchange in the Classic period Valley of Oaxaca, in: Garraty, C.P., Stark, B.L. (Eds.), Archaeological Approaches to Market Exchange in Ancient Societies. University Press of Colorado, Boulder, pp. 85-98.

Feinman, G.M., Nicholas, L.M., 2012. The late Prehispanic economy of the Valley of Oaxaca, Mexico: weaving threads from data, theory, and subsequent history, in: Matejowsky, T., Wood, D.C. (Eds.), Political Economy, Neoliberalism, and the Prehistoric Economies of Latin America. Research in Economic Anthropology Vol. 32, Emerald Group Publishing Ltd., pp. 225-258.

Feinman, G.M., Nicholas, L.M., Baker L.C., 2010. The missing femur at the Mitla Fortress and its implications. Antiq. 84, 1089-1101. 
Feinman, G.M., Nicholas, L.M., Maher, E.F., 2008. Domestic offerings at El Palmillo: implications for community organization. Anc. Mesoam. 19, 175-194.

Flannery, K.V., 1967. Vertebrate fauna and hunting patterns, in: Byers, D.S. (Ed.), The Prehistory of the Tehuacan Valley, Vol. 1, Environment and Subsistence, University of Texas Press, Austin, pp. 132-177.

Flannery, K.V., Marcus, J., 2005. Excavations at San José Mogote 1: The Household Archaeology. Museum of Anthropology Memoirs No. 40, University of Michigan, Ann Arbor.

Flannery, K.V., Wheeler, J.C., 1986. Animal food remains from preceramic Guilá Naquitz, in: Flannery, K.V. (Ed.), Guilá Naquitz: Archaic Foraging and Early Agriculture in Oaxaca, Mexico. Academic Press, N. Y., pp. 285-295.

Forde, J.E., 2015. The conquest of the place of flame: indigenous daily life at late pre-Hispanic and early colonial Achiutla, Oaxaca, Mexico. Unpublished doctoral dissertation, Department of Anthropology, University of Colorado, Boulder.

Fothergill, B.T., 2016. Reconstructing animal husbandry: trauma in Meleagris gallopavo (domestic turkey) ulnae from the American Southwest (c. AD 900-1678). J. of Archaeol. Sci.: Reports THIS VOLUME. 
Goodwin, G.C., 1969. Mammals from the State of Oaxaca, Mexico. Bulletin No. 141, American Museum of Natural History, N.Y.

Haller, M.J., Feinman, G.M., Nicholas, L.M., 2006. Socioeconomic inequality and differential access to faunal resources at El Palmillo, Oaxaca, Mexico. Anc. Mesoam. 17, 39-56.

Hamblin, N.L., 1984. Animal use by the Cozumel Maya. University of Arizona Press, Tucson.

Healy, W.M., 1992. Behavior, in: Dickson, J.G. (Ed.), The Wild Turkey: Biology and Management. Stackpole Books, Mechanicsburg, Pa., pp. 46-65.

Horcasitas, F., George, R. (Transl.), 1955. The relación de Tlacolula y Mitla. Mesoam. Notes 4, 13-24. Mexico City College, Mexico, D.F.

Howell, S.N.G., Webb, S. (1995). A Guide to the Birds of Mexico and Northern Central America. Oxford University Press, Oxford.

Hulet, R.M., Clauner, P.J., Greaser, G.L., Harper, J.K. Kime, L.F., 2004. Small-flock Turkey Production. Agricultural Research and Cooperative Extension, College of Agricultural Sciences, Pennsylvania State University, State College. 
Hurst, G.A., 1992. Foods and feeding, in: Dickson, J.G. (Ed.), The Wild Turkey: Biology and Management. Stackpole Books, Mechanicsburg, Pa., pp. 66-83.

Jones, E.L., Conrad, C., Newsome, S.D.,Kemp, B.M., Kocer, J.K., 2016. Turkeys on the fringe: variable husbandry in "marginal" areas of the prehistoric American Southwest. J. of Archaeol. Sci.: Reports THIS VOLUME.

Keepax, C.A., 1981. Avian egg-shell from archaeological sites. J. of Archaeol. Sci. 8, 315-335.

Kirkby, A.V.T., 1973. The Use of Land and Water Resources in the past and Present Valley of Oaxaca, Mexico. Museum of Anthropology Memoirs No. 5, University of Michigan, Ann Arbor.

Köng, V., Sellen, A.T., 2015. Using nineteenth-century data in contemporary archaeological studies: a view from Oaxaca and Germany, in: Zborover, D., Kroefges, P.C. (Eds), Bridging the Gaps: Integrating Archaeology and History in Oaxaca, Mexico. University Press of Colorado, Boulder, pp. 391-410.

Kowalewski, S.A., Feinman, G.M., Finsten, L., Blanton, R.E., Nicholas, L.M., 1989. Monte Albán's Hinterland Part II: Prehispanic Settlement Patterns in Tlacolula, Etla, and Ocotlán, the Valley of Oaxaca, Mexico. Museum of Anthropology Memoirs No. 23, University of Michigan, Ann Arbor. 
Lapham, H.A., 2013. Animal remains from the 2013 field season at Lambityeco, Oaxaca, Mexico. Report submitted to Gary Feinman and Linda Nicholas, Integrative Research Center, The Field Museum of Natural History, Chicago, Ill.

Lapham, H.A., Balkansky, A.K., Amadio, A.M., 2013a. Animal use at Tayata, Oaxaca, Mexico, in: Götz, C.M., Emery, K.F. (Eds.), The Archaeology of Mesoamerican Animals, Lockwood Press, Atlanta, Ga. pp. 129-151.

Lapham, H.A., Feinman, G.M., Nicholas, L.M., 2013b. Animal economies in prehispanic southern Mexico, in: Götz, C.M., Emery, K.F. (Eds.), The Archaeology of Mesoamerican Animals, Lockwood Press, Atlanta, Ga. pp. 153-190.

Lind, M., 2015. Ancient Zapotec Religion. University Press of Colorado, Boulder.

Lind, M., Urcid, J., 2010. The Lords of Lambityeco: Political Evolution in the Valley of Oaxaca during the Xoo Phase. University Press of Colorado, Boulder.

Lipp, F.J., 1991. The Mixe of Oaxaca: Religion, Ritual, and Healing. University of Texas Press, Austin.

Mallia, J.G., 1998. Indigenous domestic turkeys of Oaxaca and Quintana Roo, Mexico. Anim. Genet. Resour. Inf. 23, 69-78. 
Manin, A., Cornette, R., Lefèvre, C., 2016. Sexual dimorphism among Mesoamerican turkeys: a key for understanding past husbandry. J. of Archaeol. Sci.: Reports, THIS VOLUME.

Marcus, J., 1978. Archaeology and religion: a comparison of the Zapotec and Maya. World Archaeol. 10(2), 172-191.

Martínez-Lira, P., Corona-M., E., 2016. Possible co-existence of two species of genus Meleagris at Monte Albán, Oaxaca. J. of Archaeol. Sci.: Reports, THIS VOLUME.

Masson, M.A., Peraza Lope, C., 2013. Animal consumption at the monumental center of Mayapán, in: Götz, C.M., Emery, K.F. (Eds.), The Archaeology of Mesoamerican Animals, Lockwood Press, Atlanta, Ga. pp. 233-279.

Maxwell, E.E., 2008. Comparative embryonic development of the skeleton of the domestic turkey (Meleagris gallopavo) and other galliform birds. Zoology 111(3), 242-257.

McKusick, C.R., 1986. Southwest Indian Turkeys: Prehistory and Comparative Osteology. Southwest Bird Laboratory, Globe, Ariz.

Meir, M., Nir, A., Ar, A., 1984. Increasing hatchability of turkey eggs by matching incubator humidity to shell conductance of individual eggs. Poultry Sci. 63, 1489-1496. 
Middleton, W.D., Feinman, G.M., Nicholas, L.M., 2002. Domestic faunal assemblages from the Classic period Valley of Oaxaca, Mexico: a perspective on the subsistence and craft economies. J. of Archaeol. Sci. 29(3), 233-249.

Monteagudo, L.V., Avellanet, R., Azón, R., Tejedor, M.T., 2013. Mitochondrial DNA analysis in two heritage European breeds confirms Mesoamerican origin and low genetic variability of domestic turkey. Anim. Genet. 44, 786.

Munro, N.D., 2011. Domestication of the turkey in the American Southwest, in: Smith, B.D. (Ed.), The Subsistence Economies of Indigenous North American Societies. Smithsonian Institution Scholarly Press, Washington, D.C., pp. 543-555.

Nicholas, L.M., 1989. Land use in prehispanic Oaxaca, in: Kowalewski, S.A., Feinman, G.M., Finsten, L., Blanton, R.E., Nicholas, L.M. (Eds.), Monte Albán's Hinterland, Part II: The Prehispanic Settlement Patterns in Tlacolula, Etla and Ocotlán, The Valley of Oaxaca, Mexico. Museum of Anthropology Memoir No. 23, University of Michigan, Ann Arbor, pp. 449-505.

Paddock, J., 1983. Topic 60: Lambityeco, in: Flannery, K.V., Marcus, J. (Eds.), The Cloud People: Divergent Evolution of the Zapotec and Mixtec Civilizations. Academic Press, N.Y., pp. 190-194. 
Parsons, E.C., 1936. Mitla: Town of Souls. University of Chicago Press, Chicago.

Pelham, P.H., 1992. Physical characteristics, in: Dickson, J.G. (Ed.), The Wild Turkey: Biology and Management. Stackpole Books, Mechanicsburg, Pa., pp. 32-45.

Pérez-Lara, E., Camacho-Escobar, M.A., Ávila-Serrano, N.Y., Arroyo-Ledezma, J., SánchezBernal, E.I., Rodríguez de la Torre, M., Reyes-Borques, V., 2013. Productive evaluation of slowgrowing Mexican turkeys with different diets in confinement. Open J. of Anim. Sci. 3(1), 46-53.

Pérez Rodríguez, V., 2003. Household intensification and agrarian states: excavation of houses and terraced fields in a Mixtec cacicazgo. Unpublished doctoral dissertation, Department of Anthropology, University of Georgia, Athens.

Price, T.D., Bar-Yosef, O., 2011. The origins of agriculture: new data, new ideas: an introduction to Supplement 4. Curr. Anthro. 52(S4), S163-S174.

Rawlings, T.A., Driver, J.C., 2010. Paleodiet of domestic turkey, Shields Pueblo (5MT3807), Colorado: isotopic analysis and its implications for care of a household domesticate. J. of Archaeol. Sci. 37(10), 2433-2441.

Sahagún, F.B. de, 1959. Florentine Codex: General History of the Things of New Spain, Book 9The Merchants, transl. by Dibble, C.E., Anderson, A.J.O., Monographs of the School of 
American Research 14, Part X. University of Utah, Salt Lake City.

Schorger, A.W., 1966. The Wild Turkey: Its History and Domestication. University of Oklahoma Press, Norman.

Serpell, J. (Ed.), 1996. The Domestic Dog: Its Evolution, Behaviour and Interactions with People. Cambridge University Press, Cambridge.

Sidell, E.J., 1993. A Methodology for the Identification of Archaeological Eggshell. Supplement to Volume 10, Museum Applied Science Center for Archaeology, The University Museum of Archaeology and Anthropology, University of Pennsylvania, Phila.

Smith, B.D., 1995. The Emergence of Agriculture. W.H. Freeman, N. Y.

Smith, H.M., Smith, R.B., 1979. Synopsis of the Herpetofauna of Mexico: Vol. VI, Guide to Mexican Turtles, Bibliographic Addendum III. John Johnson, North Bennington, Vt.

Speller, C.F., Kemp, B.M., Wyatt, S.D., Monro, C., Lipe, W.D., Arndt, U.M., Yang, D.Y., 2010. Ancient mitochondrial DNA analysis reveals complexity of indigenous North American turkey domestication. PNAS 107(7), 2807-2812.

Starkman, A., 2014. A case of brideprice in a Zapotec village in Oaxaca, Mexico: anomaly 
or contribution to evolving economic theory? Can. J. of Lat. Am. and Caribb. Stud., 39(1):131138.

Starr, J., 1987. Zapotec religious practices in the Valley of Oaxaca: an analysis of the 1580 “Relaciones Geograficas” of Philip II. Can. J. of Nativ. Stud. 7(2), 367-384.

Steadman, D.W., Stull, J., Easton, S.W., 1979. Natural history of the ocellated turkey. World Pheasant Assoc. 4, 15-37.

Thornton, E.K., Emery, K.F., 2015. The uncertain origins of Mesoamerican turkey domestication. J. Archaeol. Method and Theory, published on-line Dec. 2015, DOI: $10.1007 / \mathrm{s} 10816-015-9269-4$.

Thornton, E., Emery, K.F., Speller, C., 2016. Ancient Maya turkey husbandry: testing theories through stable isotope analysis. J. of Archaeol. Sci.: Reports, THIS VOLUME.

Thornton, E.K., Emery, K.F., Steadman, D.W., Speller, C. Matheny, R., Yang, D., 2012. Earliest Mexican turkeys (Meleagris gallopavo) in the Maya region: implications for pre-Hispanic animal trade and the timing of turkey domestication. PLOS ONE 7(8), e42630.

Valadez Azua, R., García Chavez, R., Rodríguez Galicia, B., Gamboa Cabezas, L., 2001. Los guajolotes y la alimentación prehispánica. Cienc. y Desarro. 157, 55-63. 
Valadez Azúa, R., Rodríguez Galicia, B., 2014. Uso de la fauna, estudios arqueozoológicos y tendencias alimentarias en culturas prehispánicas del centro de México. An. de Antropol. 48-I, 139-166.

Vigne, J.-D., Peters, J., Helmer, D. (Eds.), 2005. The First Steps of Animal Domestication: New Archaeological Approaches. Oxbow Books, Oxford.

Whalen, M.E., 1981. Excavations at Santo Domingo Tomaltepec: Evolution of a Formative Community in the Valley of Oaxaca, Mexico. Museum of Anthropology Memoirs No. 12, University of Michigan, Ann Arbor.

Whitehead, C.C., 2004. Overview of bone biology in the egg-laying hen. Poult. Sci. 83(2), 193199.

Winter, M.C., 1972. Tierras Largas: A Formative community in the Valley of Oaxaca, Mexico. Unpublished Ph.D. dissertation, Department of Anthropology, University of Arizona, Tucson.

Zeder, M.A., 2006. Central questions in the domestication of plants and animals. Evol. Anthro. $15,105-117$.

Zeder, M.A., 2015. Core questions in domestication research. PNAS, 112(11), 3191-3198. 
Zeder, M.A., Bradley, D., Emshwiller, E., Smith, B.D. (Eds.), 2006. Documenting

Domestication: New Genetic and Archaeological Paradigms. University of California Press, Oakland.

Zeitlan, J.F., 2015. Locating the hidden transcripts of colonialism: archaeological and historical evidence from the Isthmus of Tehuantepec, in: Zborover, D., Kroefges, P.C. (Eds.), Bridging the Gaps: Integrating Archaeology and History in Oaxaca, Mexico. University Press of Colorado, Boulder, pp. 363-390. 


\section{FIGURE CAPTIONS}

Figure 1. Turkeys at the market in Tlacolula, a town $10 \mathrm{~km}$ west of Mitla.

Figure 2. Map of the Central Valleys of Oaxaca showing the location of sites mentioned in the text. Illustrations and photographs are by Linda Nicholas unless otherwise noted.

Figure 3. Photograph of the Mitla Fortress showing the location of excavated terraces.

Figure 4. Turkey femur with medullary bone viewed from the a) posterior perspective, and b) proximal end of the shaft. Photograph by Heather Lapham.

Figure 5. Bone awls from Terraces 56 and 57. Two turkey specimens are marked by arrows.

Figure 6. Plan view of Terraces 56 and 57 showing the location of turkey offerings.

Figure 7. In situ photograph of turkey eggs and poults from a ritual offering (Offering 9) on Terrace 56.

Figure 8. The most complete skeletal elements from the turkey poults and the largest pieces of the unhatched eggs from Offering 9. Right (top to bottom): mandibles, coracoids, humeri, femora, tibiotarsi, tarsometatarsi. Left: eggshell. 
Figure 9. SEM micrographs of turkey eggshell from the Mitla Fortress showing different degrees of mammillary cone resorption, a) no resorption, $0-16$ days, b) minimal resorption, ca. 22 days, c) minimal to significant resorption, ca. 22-24 days, d) significant resorption, ca. 24-26 days, e) significant resorption, ca. 26 days, and f) significant resorption, ca. 28-29 days, hatching or hatched egg. Estimated days into the incubation period based on Beacham and Durand (2007:figure 3). Photographs produced at the Integrated Microscopy and Graphics Expertise (IMAGE) facility, Southern Illinois University. 
Table 1

Animals identified in the faunal assemblage of Terraces 56 and 57 listed in rank order by NISP. The table includes specimens identified to the taxonomic level of infraclass and lower that could be assigned to an occupation period. It excludes commensal taxa, modified animal remains, and fauna from offering and mortuary contexts.

\begin{tabular}{ll}
\hline Common name & Scientific name \\
\hline domestic dog & Canis familiaris \\
turkey & Meleagris gallopavo \\
white-tailed deer & Odocoileus virginianus \\
cottontail rabbits & Sylvilagus spp. \\
jackrabbits & Lepus spp. \\
Mexican mud turtle & Kinosternon integrum \\
hooded skunk & Mephitis macroura \\
turtles & Testudines order \\
giant pocket gopher & Orthogeomys grandis \\
mexican gray squirrel & Sciurus aureogaster \\
rabbits & Leporidae order \\
opossum & Didelphis marsupialis \\
long-tailed weasel & Mustela frenata \\
nine-banded armadillo & Dasypus novemcinctus \\
hawks & Accipitridae family \\
Montezuma quail & Cyrtonyx montezumae \\
barred owl & Strix varia \\
zenaida doves & Zenaida spp. \\
Central American river turtle & Dermatemys mawii \\
bobcat & Lynx rufus \\
great horned owl & Bubo virginianus \\
\hline
\end{tabular}


Table 2

List of turkey remains identified in the faunal assemblage of Terraces 56 and 57. Skeletal element terminology follows Olsen (1968).

\begin{tabular}{lc} 
Head & Wing, continued \\
mandible & carpal, scapholunar \\
skull & wing digit I, pollex \\
skull, premaxilla & wing digit II, phalanx 1 \\
skull, nasal & wing digit II, phalanx 2 \\
skull, frontal & wing digit III \\
skull, quadrate & Limb \\
Axial/Breast & femur \\
rib & tibiotarsus \\
vertebra & fibula \\
vertebra, axis & Foot \\
vertebra, cervical & tarsometatarsus \\
vertebra, caudal & metatarsal 1 \\
vertebra, ossified tendon & digit I, phalanx 1 \\
coracoid & digit $\mathrm{x}$, phalanx 1 \\
scapula & digit $\mathrm{x}$, phalanx 2 \\
sternum & digit $\mathrm{x}$, phalanx 3 \\
pelvis & digit $\mathrm{x}$, phalanx 4 \\
pelvis, acetabulum & digit $\mathrm{x}$, phalanx x \\
Wing & digit x, ungus \\
humerus & Egg \\
radius & egg, whole \\
ulna & egg, partial \\
carpometacarpus & eggshell \\
carpal, cuneiform & \\
\hline
\end{tabular}


Table 3

Percent NISP of turkey and other taxa compared among terraces at the Mitla Fortress. Summary data for Terraces 56 and 57 are provided in Lapham et al. (2013:table 3), with raw data presented in Lapham et al. (2013:table 5). Terrace 276 represents new data. The table includes specimens identified to the taxonomic level of infraclass and lower, with the exception of bony fishes (Osteichthyes superclass) included in the other taxa category, that could be assigned to an occupation period. The table excludes commensal taxa, modified animal remains, and fauna from offering and mortuary contexts.

\begin{tabular}{lcccc}
\hline \multirow{2}{*}{ Taxa } & \multicolumn{2}{c}{ Terraces $56 \& 57$} & \multicolumn{2}{c}{ Terrace 276} \\
& NISP & $\%$ & NISP & $\%$ \\
\hline Deer & 78 & 10.3 & 44 & 18.6 \\
Dog & 247 & 32.7 & 64 & 27.0 \\
Rabbits & 118 & 15.6 & 47 & 19.8 \\
Turkey & 207 & 27.4 & 41 & 17.3 \\
Other taxa & 105 & 13.9 & 41 & 17.3 \\
\hline Totals & 755 & $100 \%$ & 237 & $100 \%$ \\
\hline
\end{tabular}


Table 4

Percent NISP of turkey and other taxa compared among other sites in the Central Valleys of Oaxaca. Summary data for El Palmillo and Ejutla are provided in Lapham et al. (2013:table 3), with raw data for El Palmillo presented in Lapham et al. (2013:table 4). Ejutla counts are from Middleton et al. (2002:table 3). Lambityeco represents new data. The table includes specimens identified to the taxonomic level of infraclass and lower, with the exception of bony fishes (Osteichthyes superclass) included in the other taxa category, that could be assigned to an occupation period. The table excludes commensal taxa, modified animal remains, and fauna from offering and mortuary contexts.

\begin{tabular}{lcccccc}
\hline \multirow{2}{*}{ Taxa } & \multicolumn{2}{c}{ El Palmillo } & \multicolumn{2}{c}{ Lambityeco } & \multicolumn{2}{c}{ Ejutla } \\
& NISP & $\%$ & NISP & $\%$ & NISP & $\%$ \\
\hline Deer & 715 & 19.7 & 49 & 6.2 & 259 & 19.4 \\
Dog & 1192 & 32.8 & 410 & 51.8 & 504 & 37.7 \\
Rabbits & 1393 & 38.3 & 222 & 27.1 & 278 & 20.8 \\
Turkey & 200 & 5.5 & 51 & 6.4 & 5 & .4 \\
Other taxa & 137 & 3.8 & 59 & 7.5 & 292 & 21.8 \\
\hline Totals & 3637 & $100 \%$ & 791 & $100 \%$ & 1338 & $100 \%$ \\
No. of residences & & 8 & & & & 1 \\
in sample & & & & & & \\
\hline
\end{tabular}


Table 5

Modified turkey, bird, and other animal remains compared between the Mitla Fortress and other sites in the Central Valleys of Oaxaca. Count precedes percent (in parentheses).

\begin{tabular}{lccccc}
\hline & $\begin{array}{c}\text { Mitla Fortress } \\
\text { T. 56 \& 57 }\end{array}$ & $\begin{array}{c}\text { Mitla Fortress } \\
\text { T. 276 }\end{array}$ & El Palmillo & $\begin{array}{c}\text { Lambityec } \\
\text { o }\end{array}$ & Ejutla \\
\hline Turkey & $6(4.1)$ & $0(0.0)$ & $2(0.4)$ & $9(7.7)$ & $2(2.4)$ \\
$\begin{array}{l}\text { Unidentified bird } \\
\text { Other animal }\end{array}$ & $27(18.2)$ & $5(8.5)$ & $13(2.4)$ & $10(8.5)$ & $1(1.2)$ \\
Total counts & $115(77.7)$ & $54(91.5)$ & $525(97.2)$ & $98(83.8)$ & $79(96.3)$ \\
$\begin{array}{l}\% \text { turkey of all } \\
\text { modified remains }\end{array}$ & $4 \%$ & 59 & 540 & 117 & 82 \\
$\%$ all bird of all & $22 \%$ & $0 \%$ & $<1 \%$ & $8 \%$ & $2 \%$ \\
modified remains & & $9 \%$ & $3 \%$ & $16 \%$ & $4 \%$ \\
\hline
\end{tabular}


Table 6

Scanning electron microscope results of the avian eggshell analyses from Terraces 56 and 57 at the Mitla Fortress. Cone resorption categories for archaeological specimens are based on Beacham and Durand (2007): none or no resorption, days zero to 16 of incubation (NR), minimal resorption, days 18 to 22 of incubation (MR), and significant resorption, days 24 to hatching (SR). Approximate days compares the Mitla Fortress specimens to the patterned progression of bone resorption on modern turkey eggshell at zero, 18, 20, 22, 24, and 26 days of incubation and hatched $(\mathrm{H})$ eggshell as observed by Beacham and Durand (2007:figure 3).

\begin{tabular}{|c|c|c|c|c|c|c|c|c|}
\hline \multirow{2}{*}{$\begin{array}{c}\text { Terrace \& } \\
\text { Bag No. }\end{array}$} & \multirow{2}{*}{$\begin{array}{l}\text { Occupation } \\
\text { Period }\end{array}$} & \multirow{2}{*}{ Unit } & \multirow{2}{*}{ Context } & \multirow{2}{*}{ Element } & \multirow{2}{*}{$\begin{array}{c}\text { SEM } \\
\text { Taxa ID }\end{array}$} & \multicolumn{2}{|c|}{ Degree of Cone Resorption } & \multirow{2}{*}{$\begin{array}{c}\text { Approx. } \\
\text { Days }\end{array}$} \\
\hline & & & & & & Specimen A & Specimen B & \\
\hline \multicolumn{9}{|l|}{ Terrace 56} \\
\hline 576 & S.2 residence & $12 \mathrm{n} 12 \mathrm{e}$ & Offering 9 & Egg (whole) & Turkey & MR & n.a. & 22 \\
\hline 706 & S.1 residence & $6 n 20 e$ & Scattered ash from pit & Eggshell & Turkey & SR & n.a. & $26-\mathrm{H}$ \\
\hline 716 & S.1 residence & $4 n 20 \mathrm{e}$ & Exterior ashy area & Egg (whole) & Turkey & SR & n.a. & $24-26$ \\
\hline \multicolumn{9}{|l|}{ Terrace 57} \\
\hline 10 & Post-residential & $8 \mathrm{n} 24 \mathrm{e}$ & Exterior area & Eggshell & Turkey & SR & n.a. & $\mathrm{H}$ \\
\hline 195 & S.1 residence & $12 \mathrm{n} 24 \mathrm{e}$ & Offering 19 & Egg (whole) & Turkey & MR-SR & MR-SR & $22-24$ \\
\hline 246 & $\mathrm{~S} .1$ residence & $12 \mathrm{n} 26 \mathrm{e}$ & North room wall & Egg (partial) & Turkey & SR & SR & $26-\mathrm{H}$ \\
\hline 301 & S.1 residence & $8 \mathrm{n} 24 \mathrm{e}$ & Offering 21 & Egg (partial) & Turkey & SR & SR & $\mathrm{H}$ \\
\hline 382 & $\mathrm{~S} .1$ residence & $10 \mathrm{n} 30 \mathrm{e}$ & North room floor & Eggshell & Turkey & NR & n.a. & 0 \\
\hline 394 & S. 2 residence & $8 \mathrm{n} 24 \mathrm{e}$ & Burial 26 offering & Eggshell & Turkey & SR & n.a. & $\mathrm{H}$ \\
\hline 434 & $\mathrm{~S} .2$ residence & $4 n 24 \mathrm{e}$ & Burial 27 fill & Eggshell & Turkey & SR & n.a. & $\mathrm{H}$ \\
\hline 440 & S.2 residence & $8 \mathrm{n} 24 \mathrm{e}$ & Burial 26 offering & Egg (partial) & Turkey & SR & SR & $\mathrm{H}$ \\
\hline
\end{tabular}




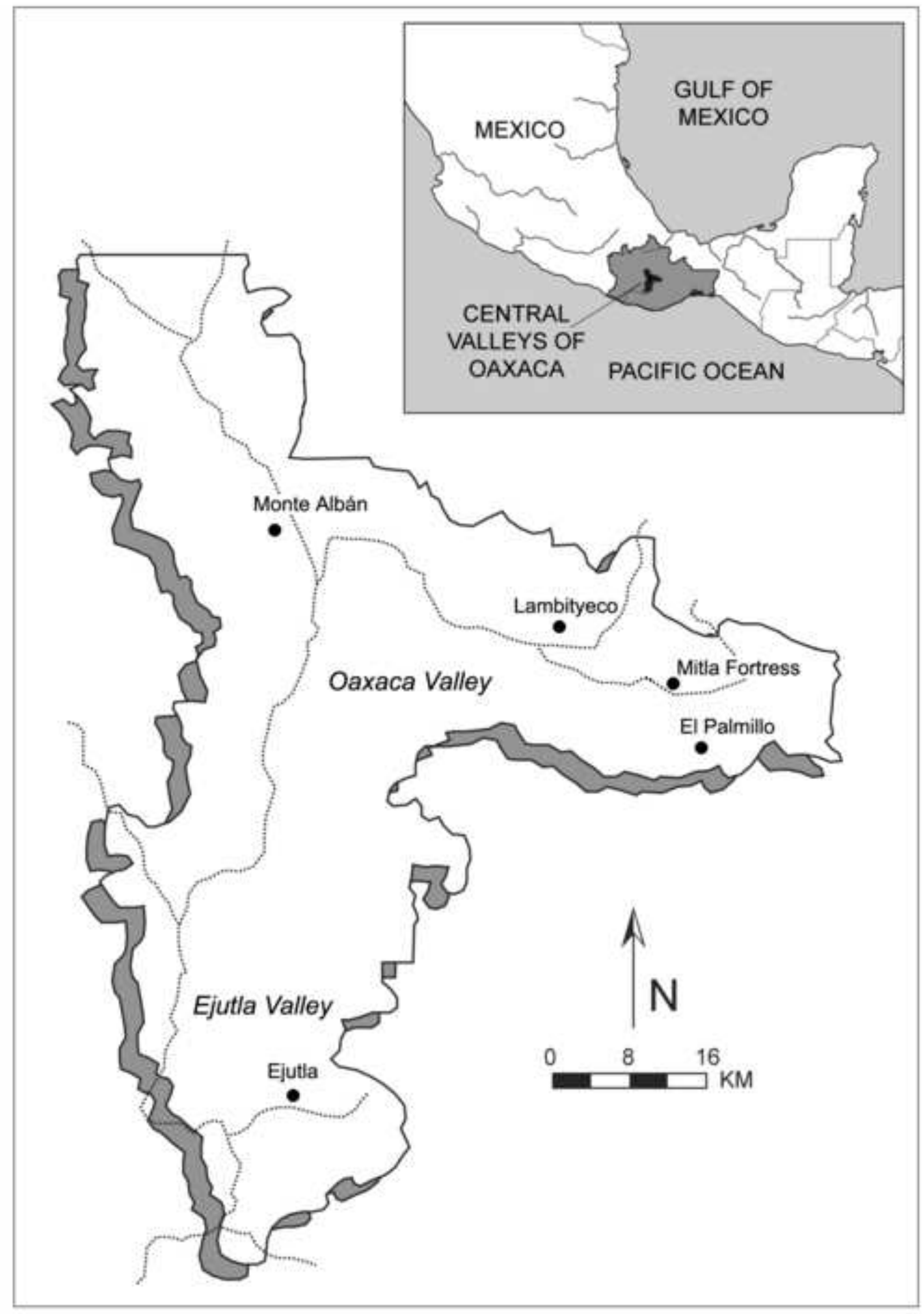

Figure 2 


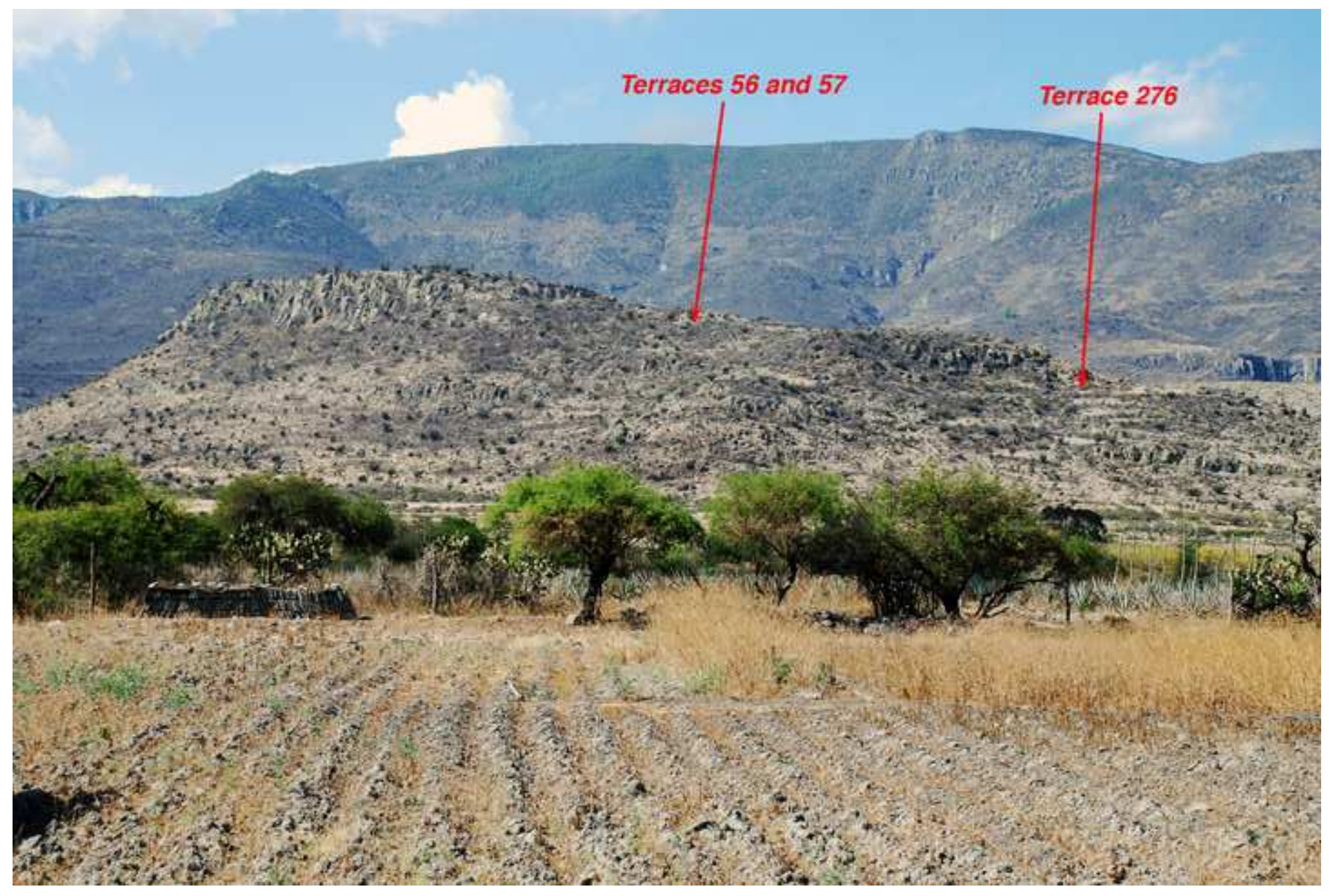

3.

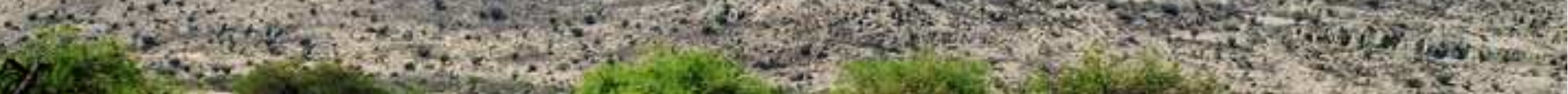

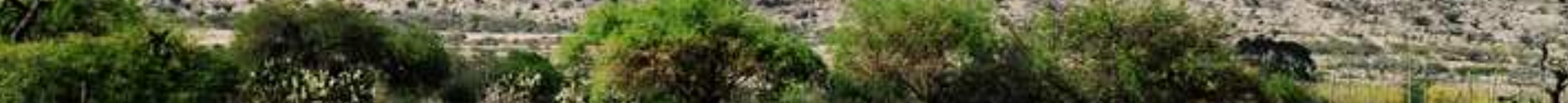
7.2. W.

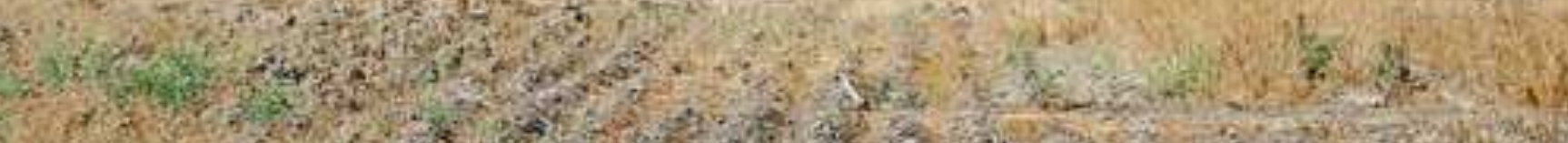

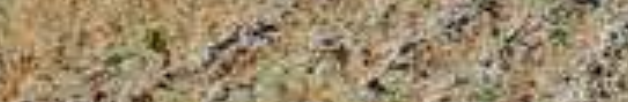

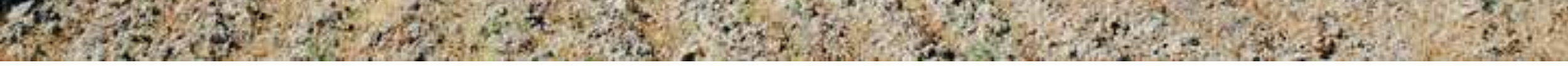


Figure 4
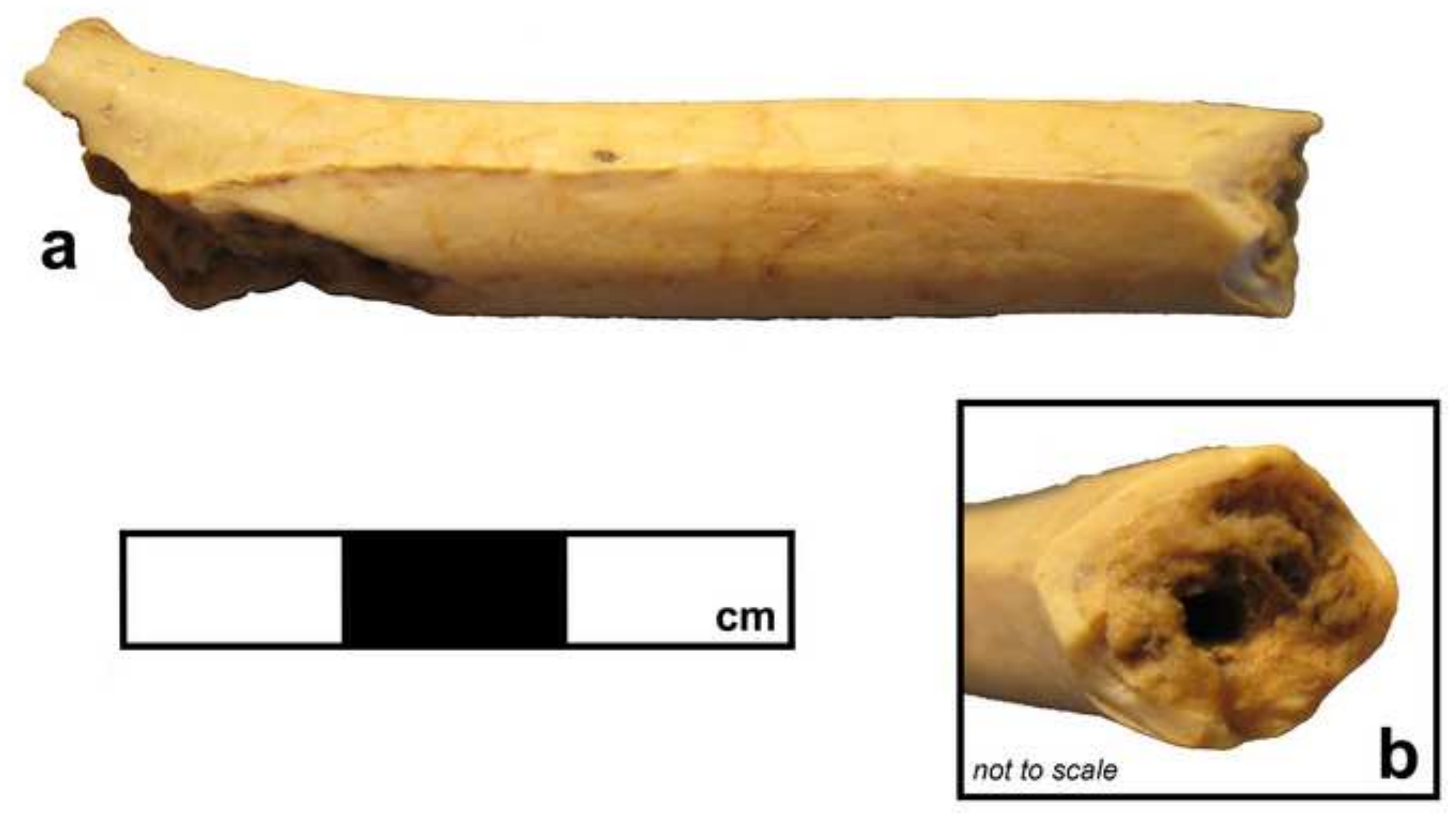

a

. 


$$
\text { iill lin }
$$




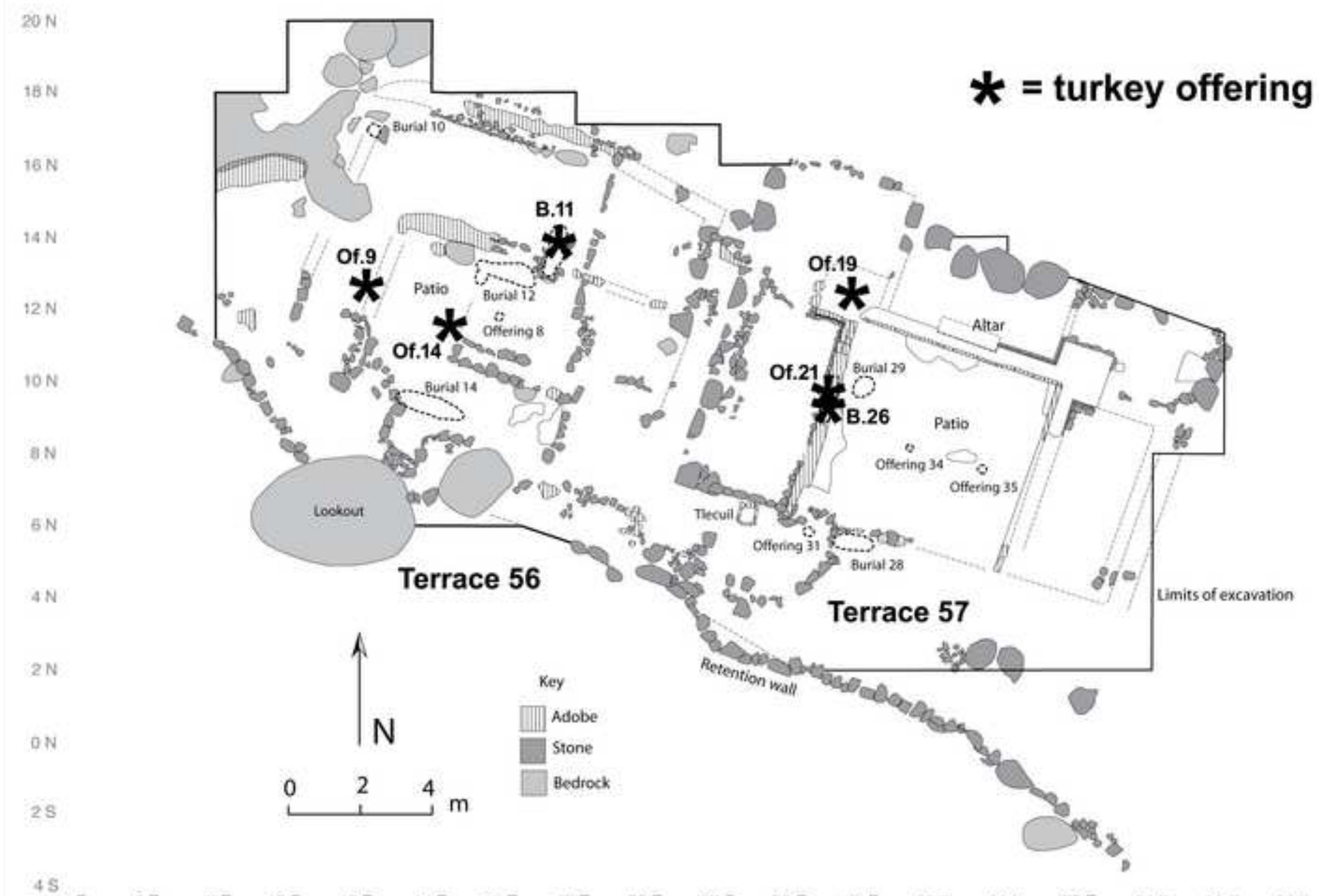

20



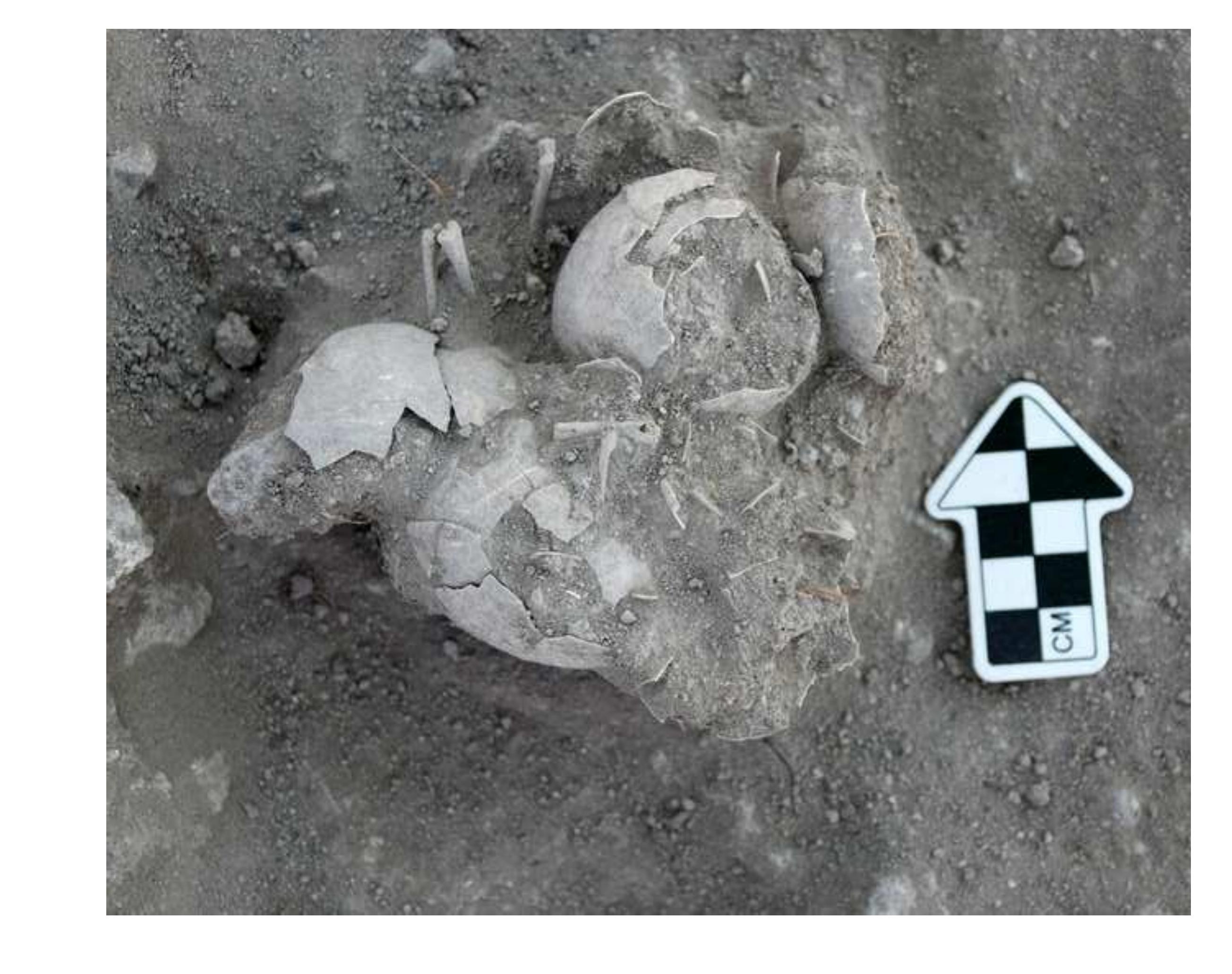

$-$
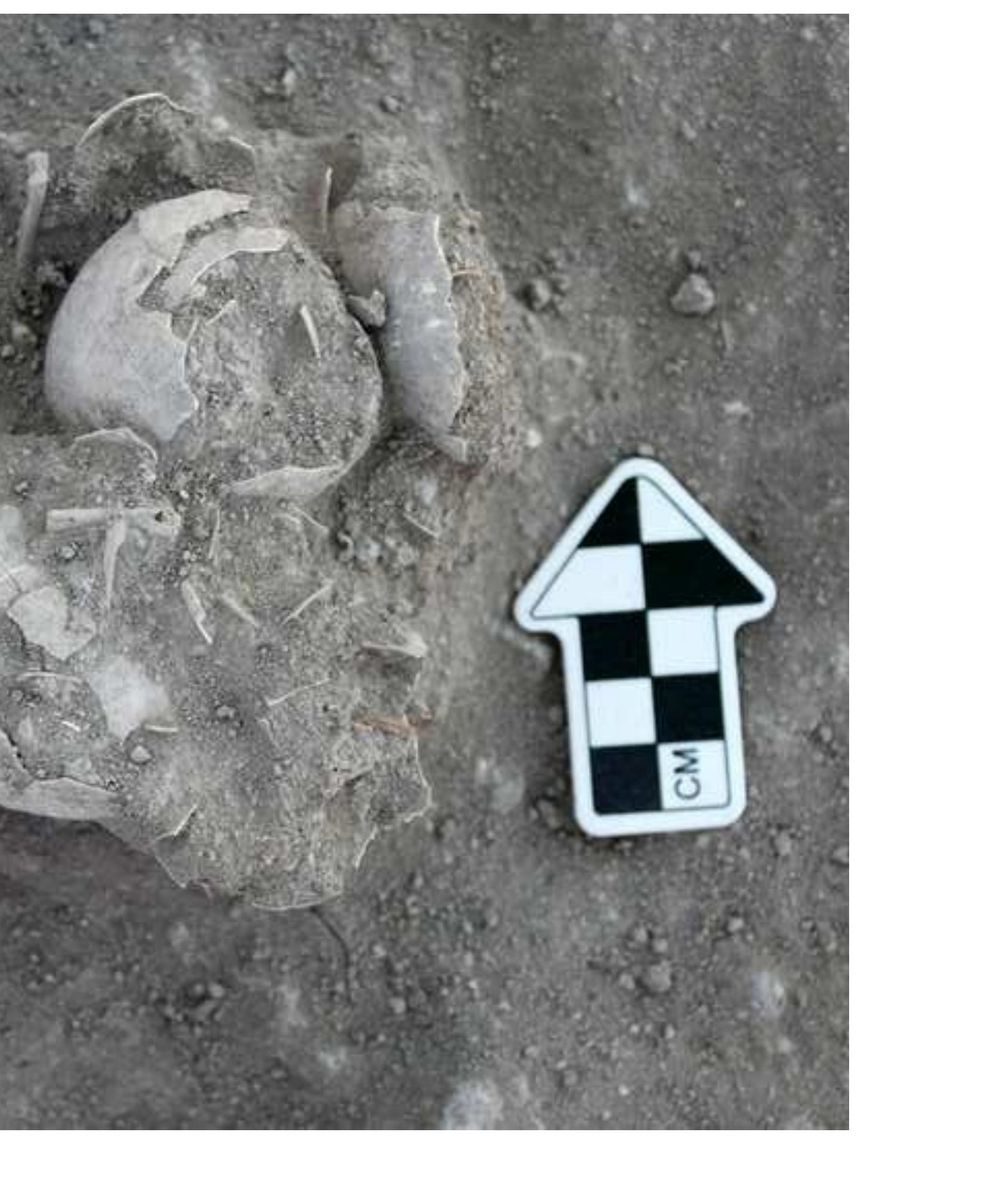

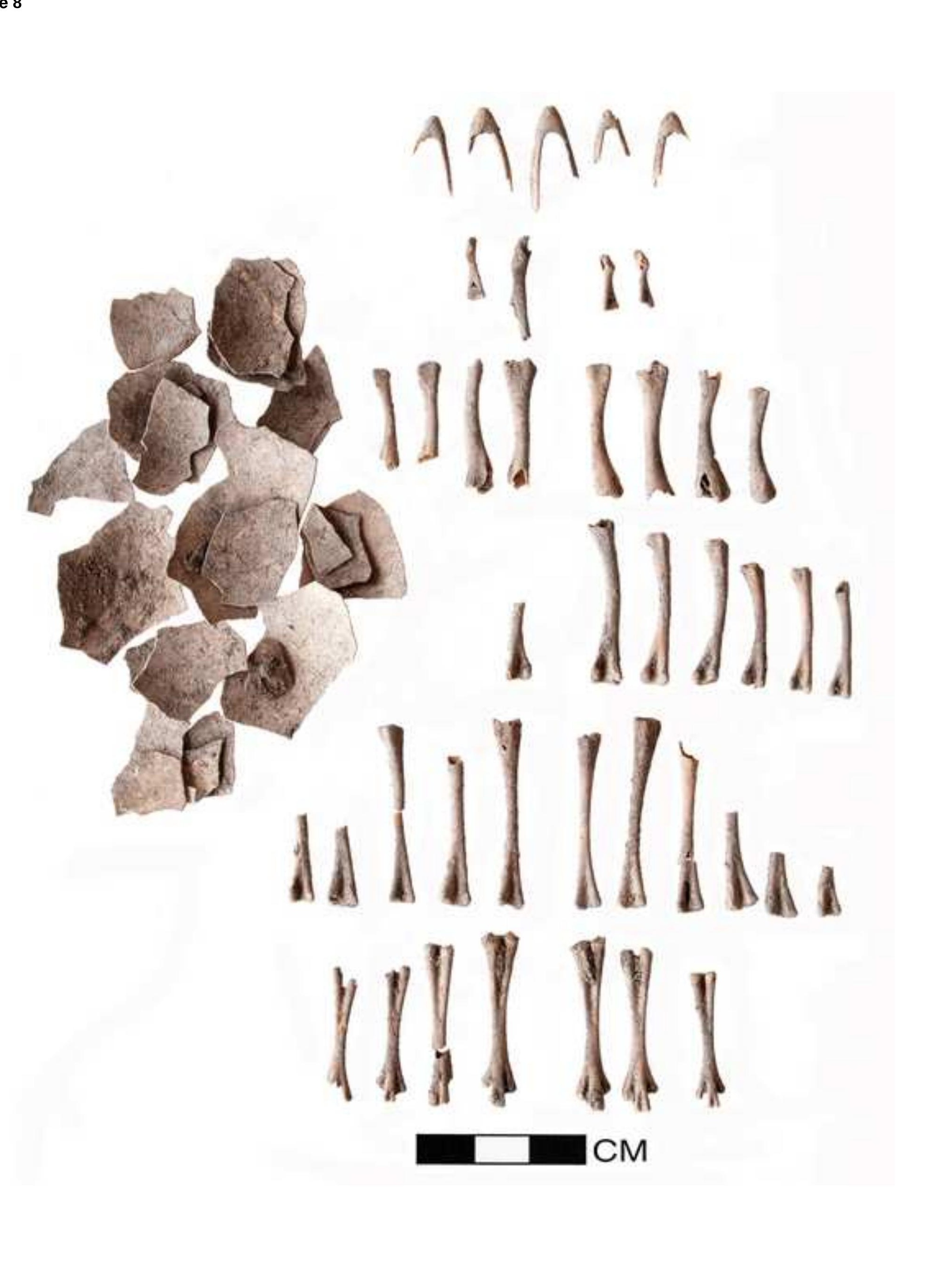

Figure 8

AAAP

Figure 8

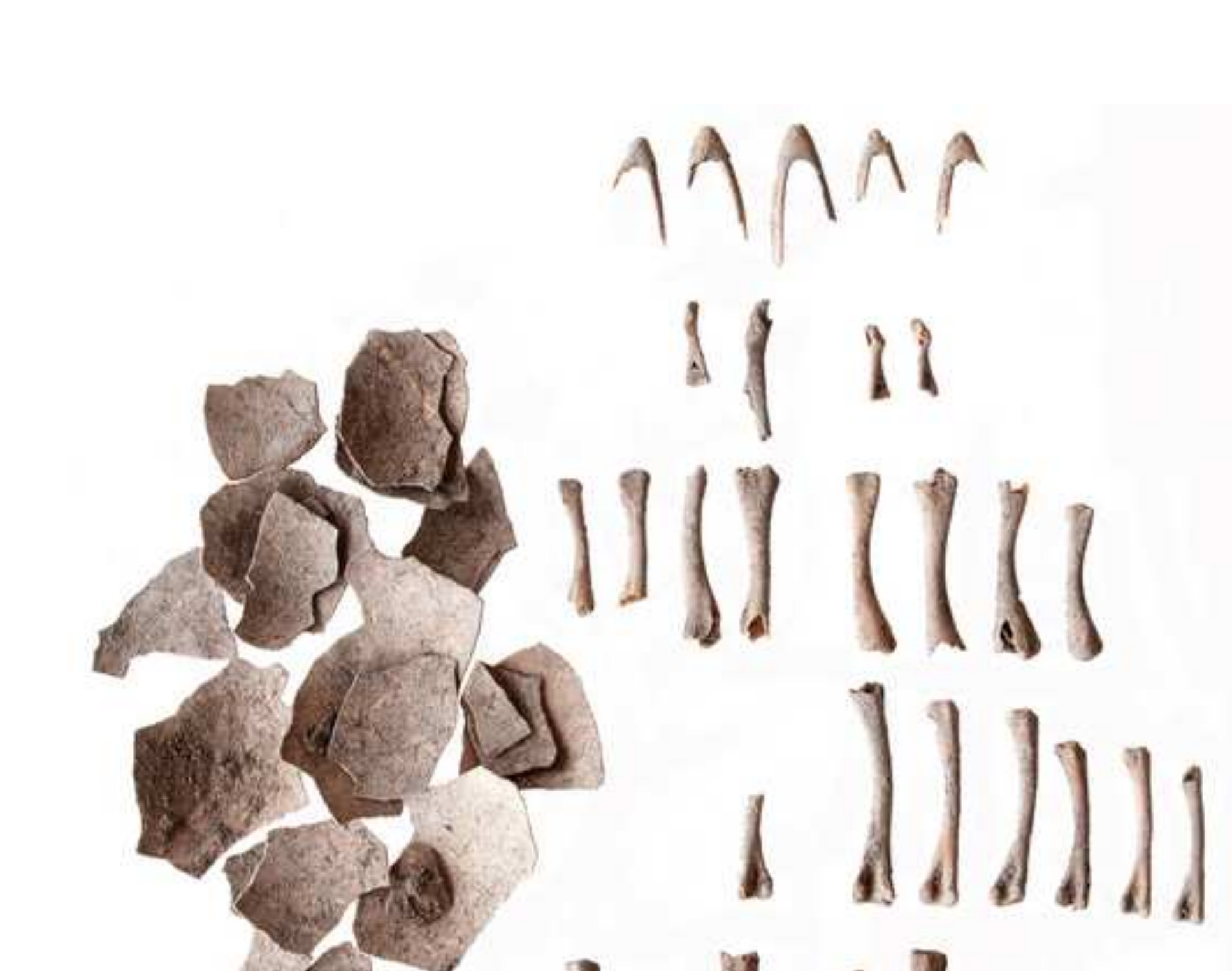

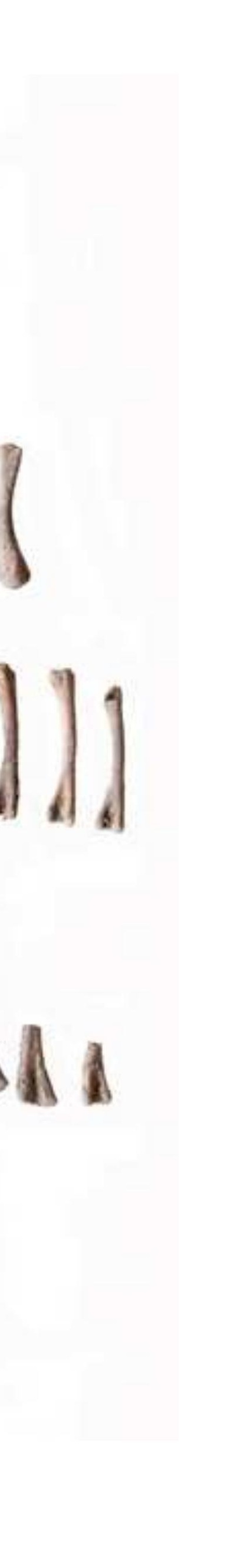




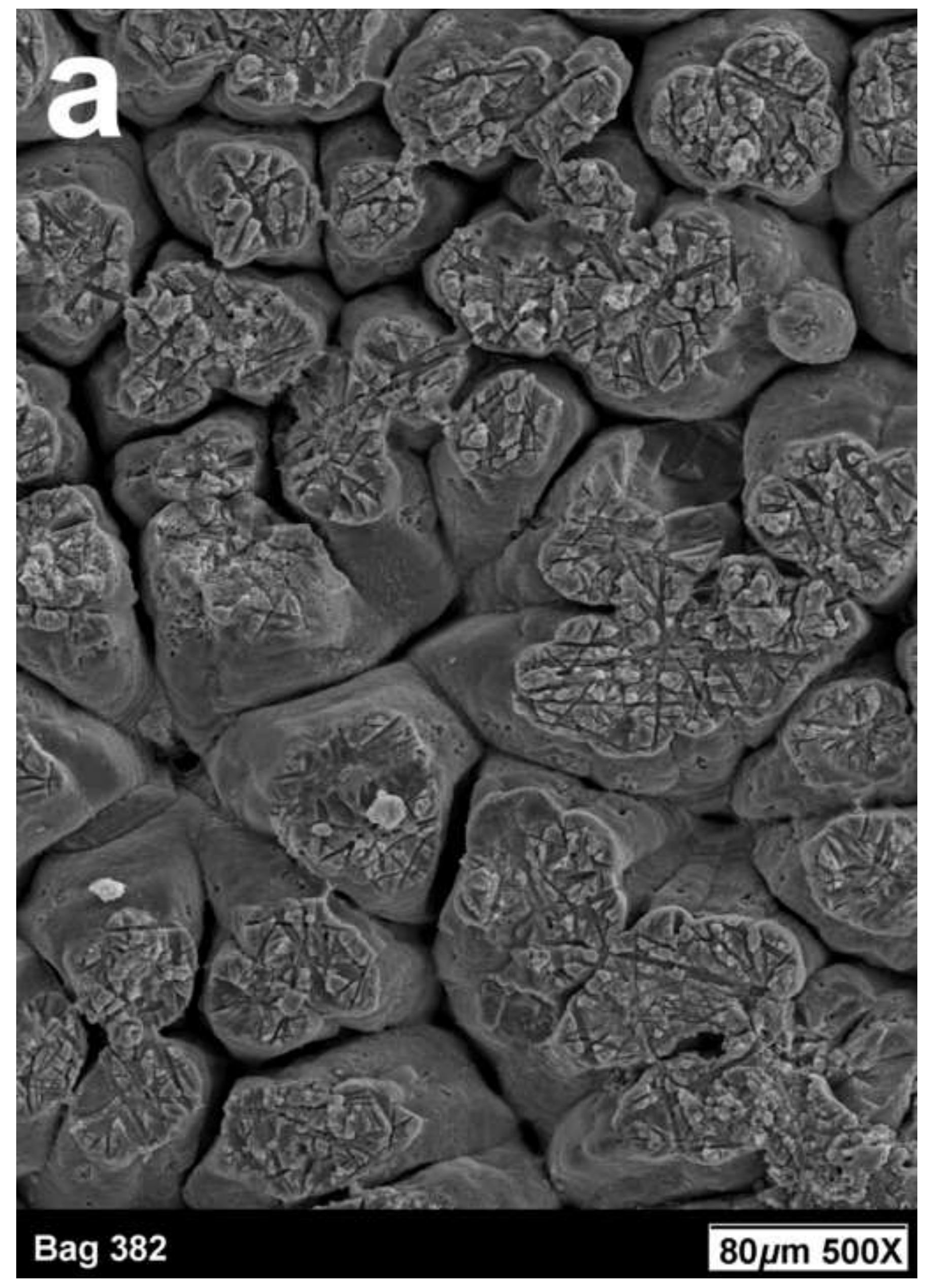




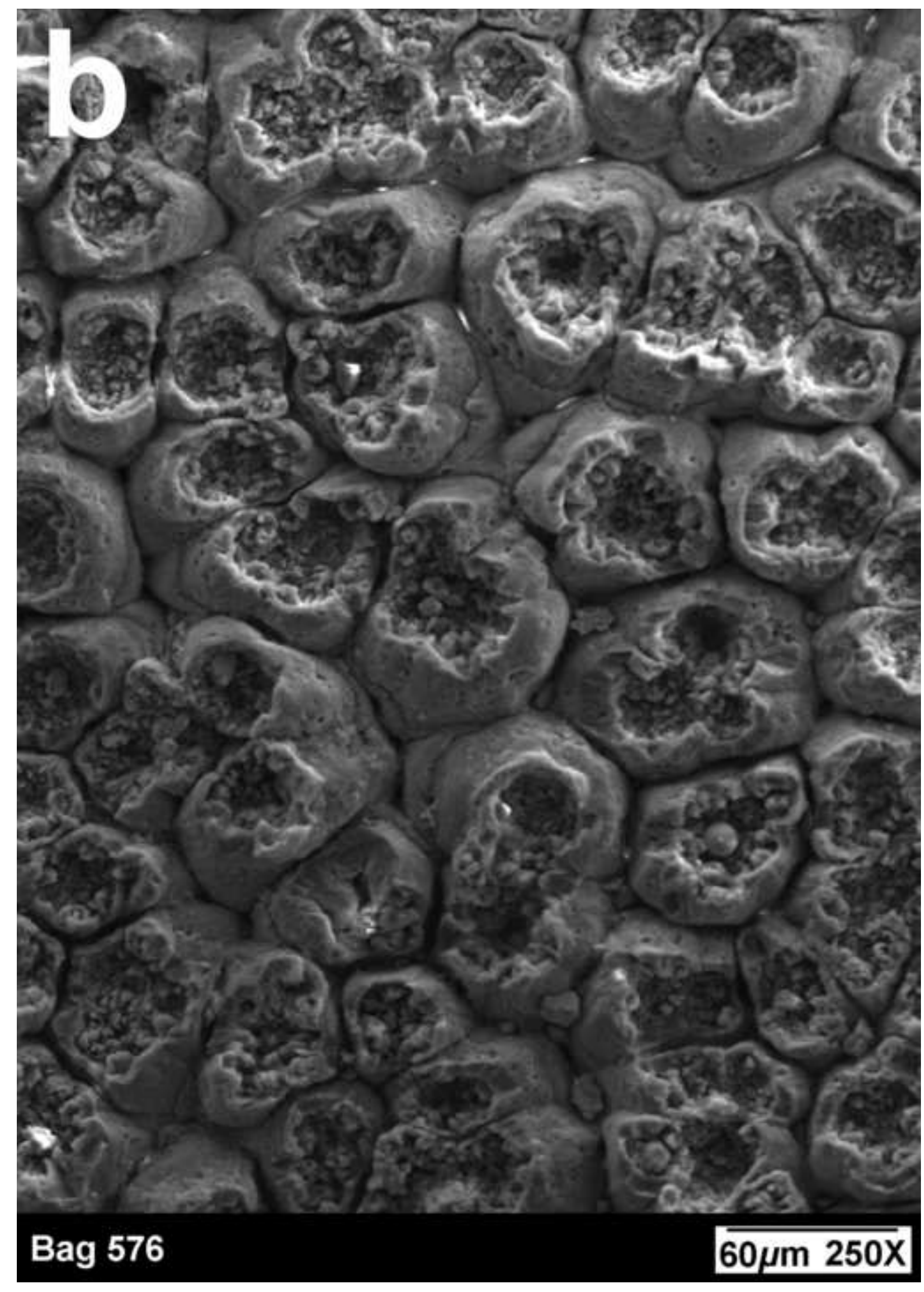

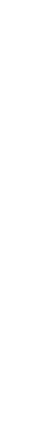

\section{Figure}

.

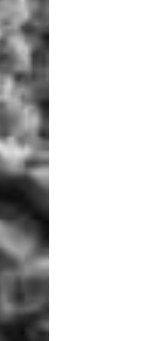

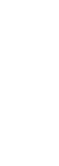

$$
\text { . }
$$




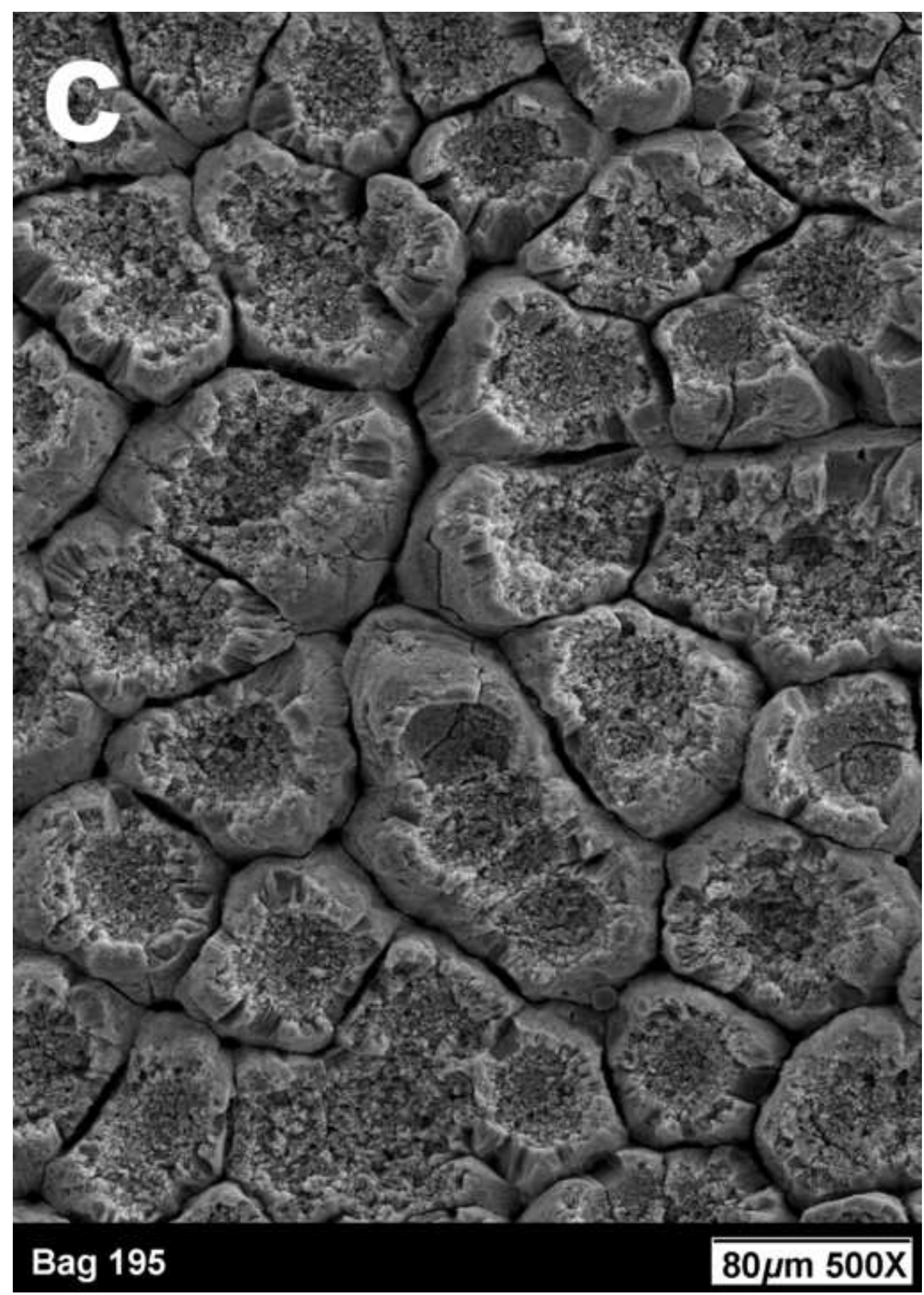

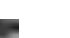

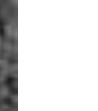

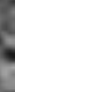

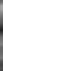



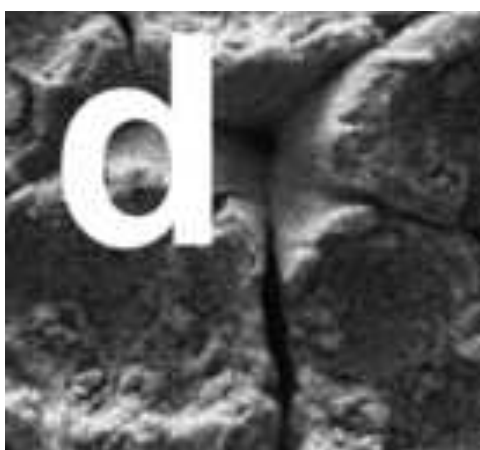

B.
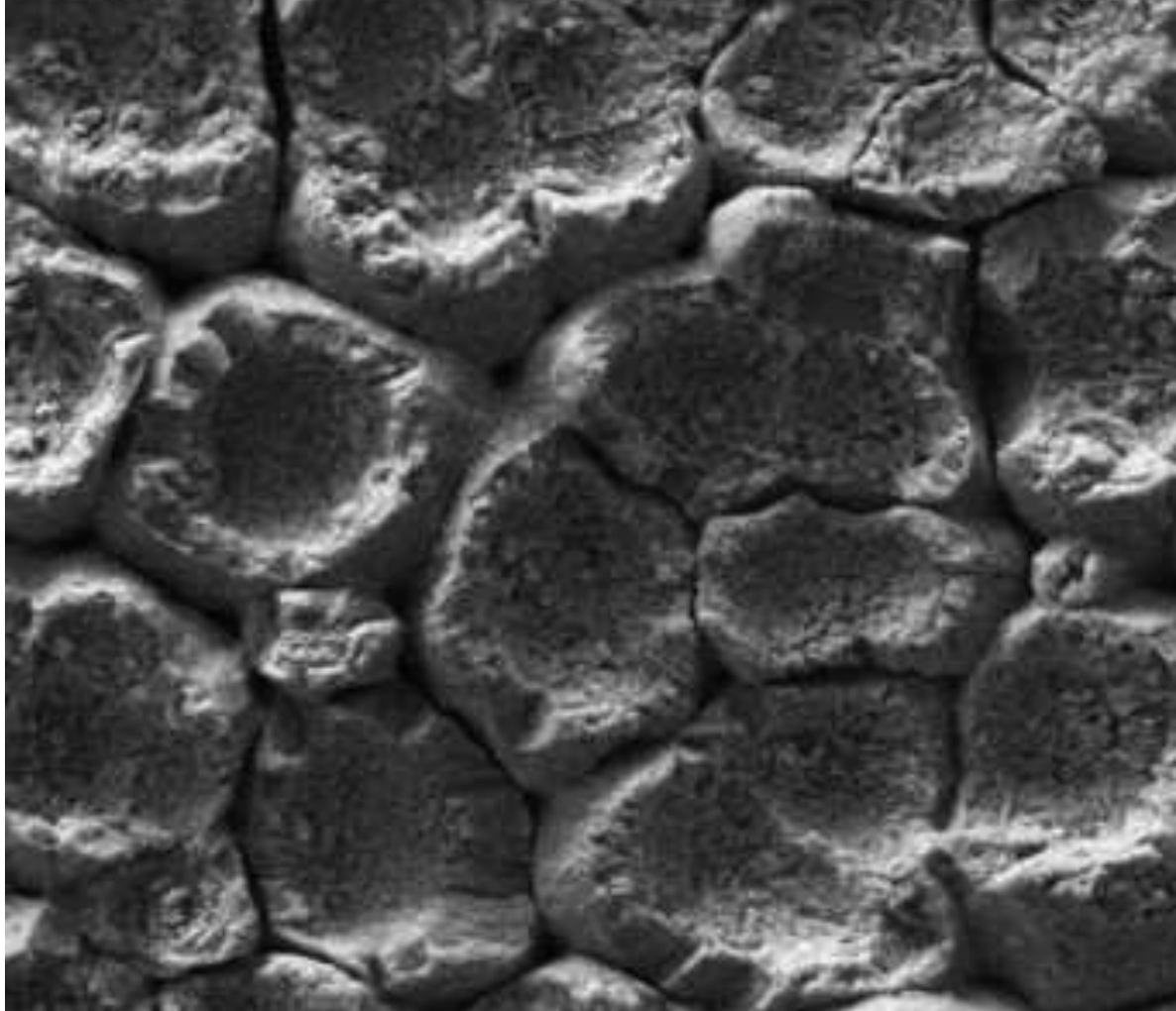

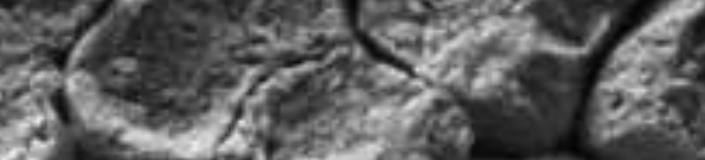

30

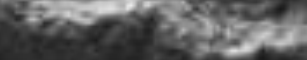
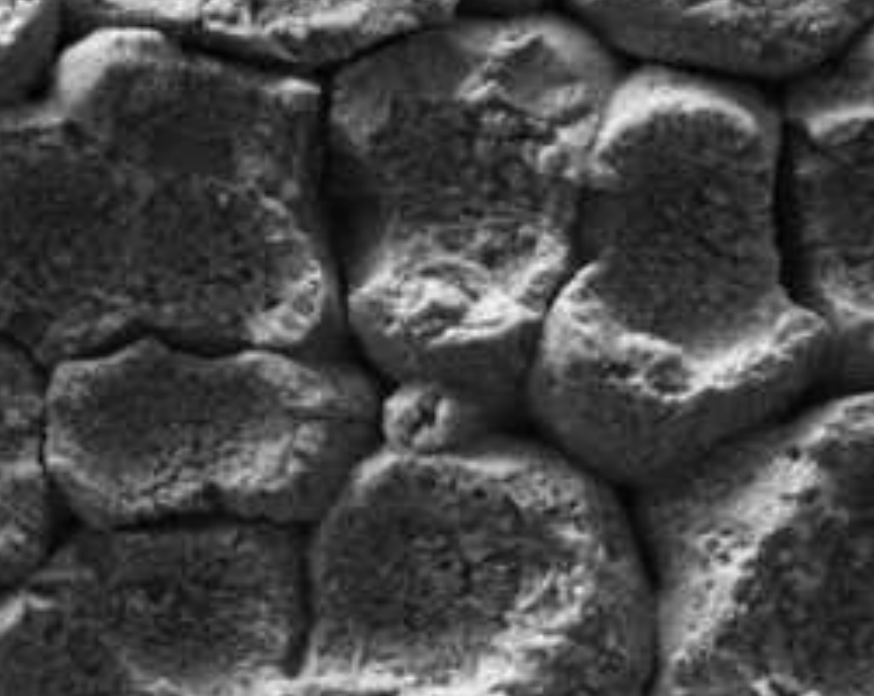
is

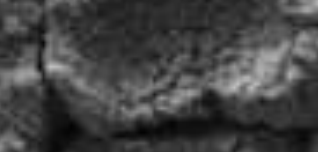

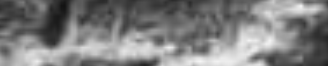

$\log _{0}$
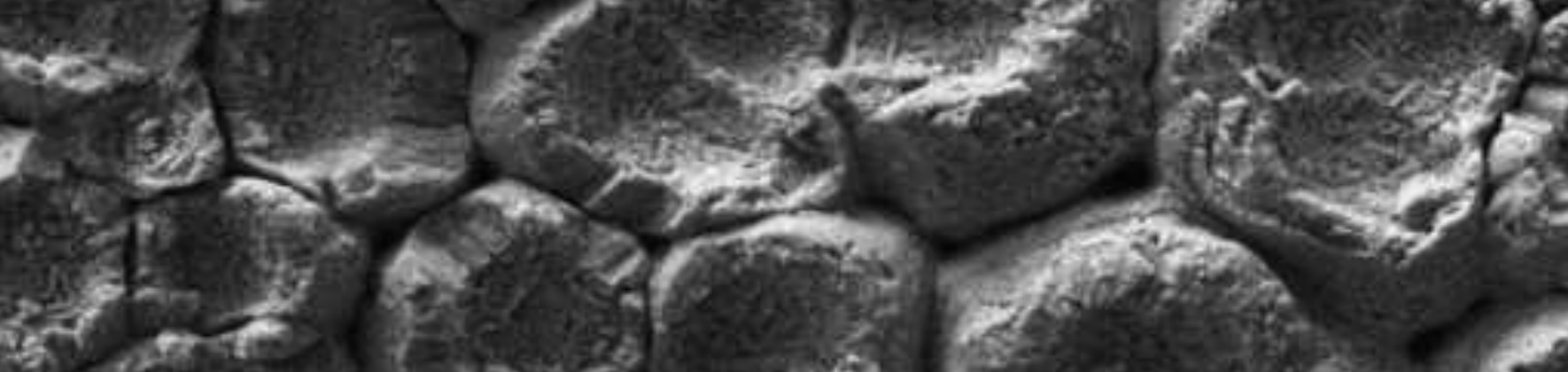

I.

3)
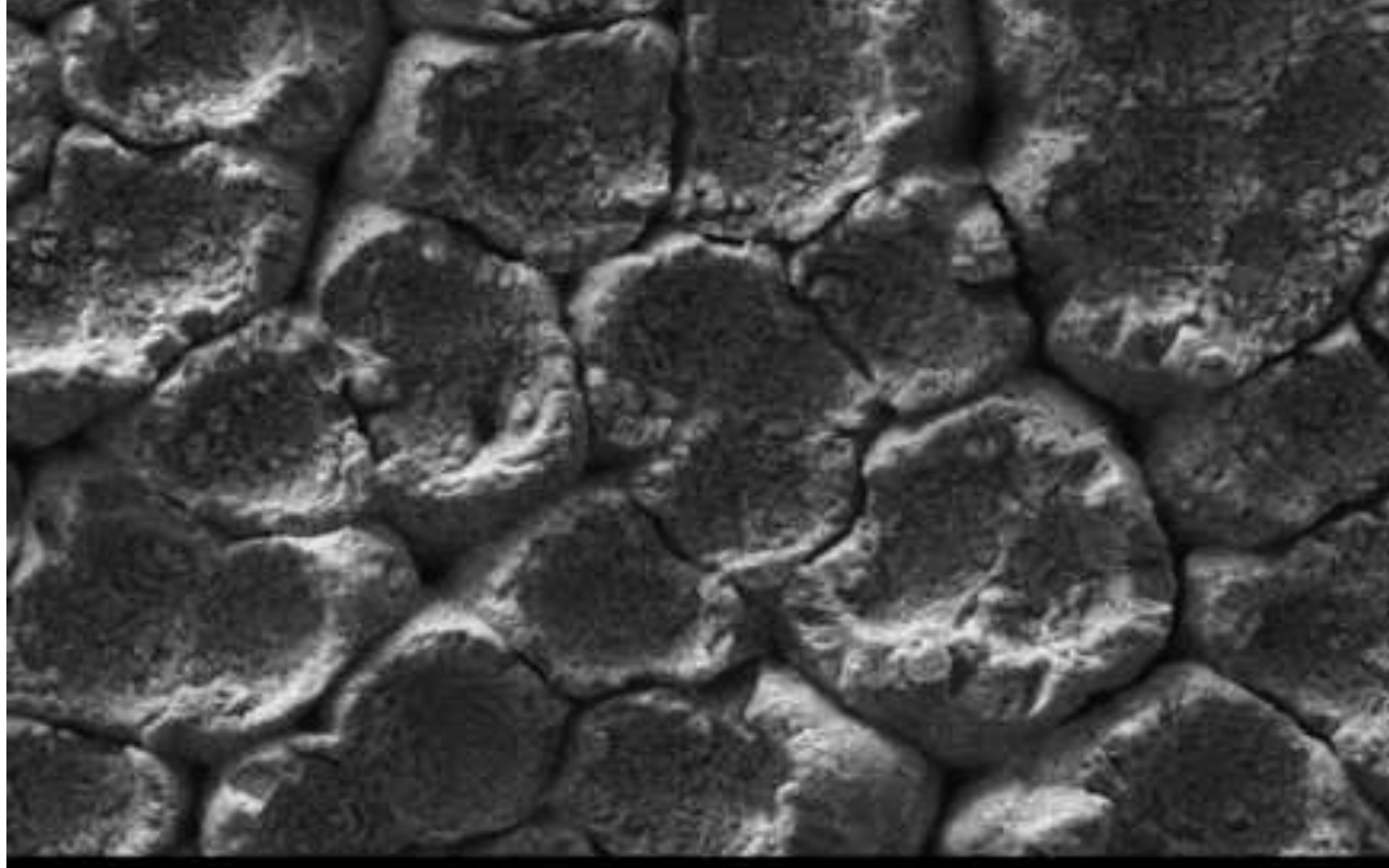

Bag 716

$60 \mu \mathrm{m} \mathrm{250X}$ 


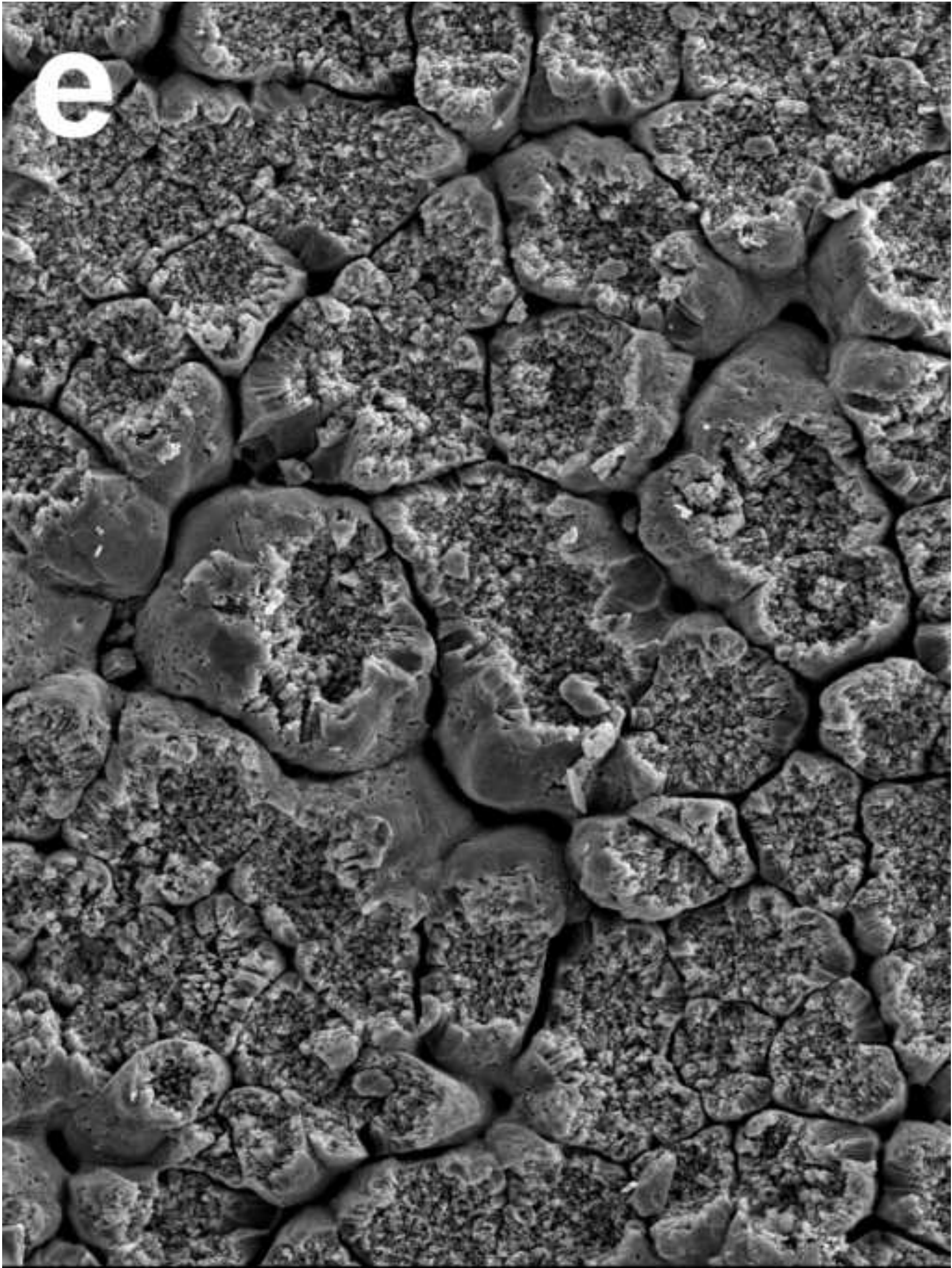




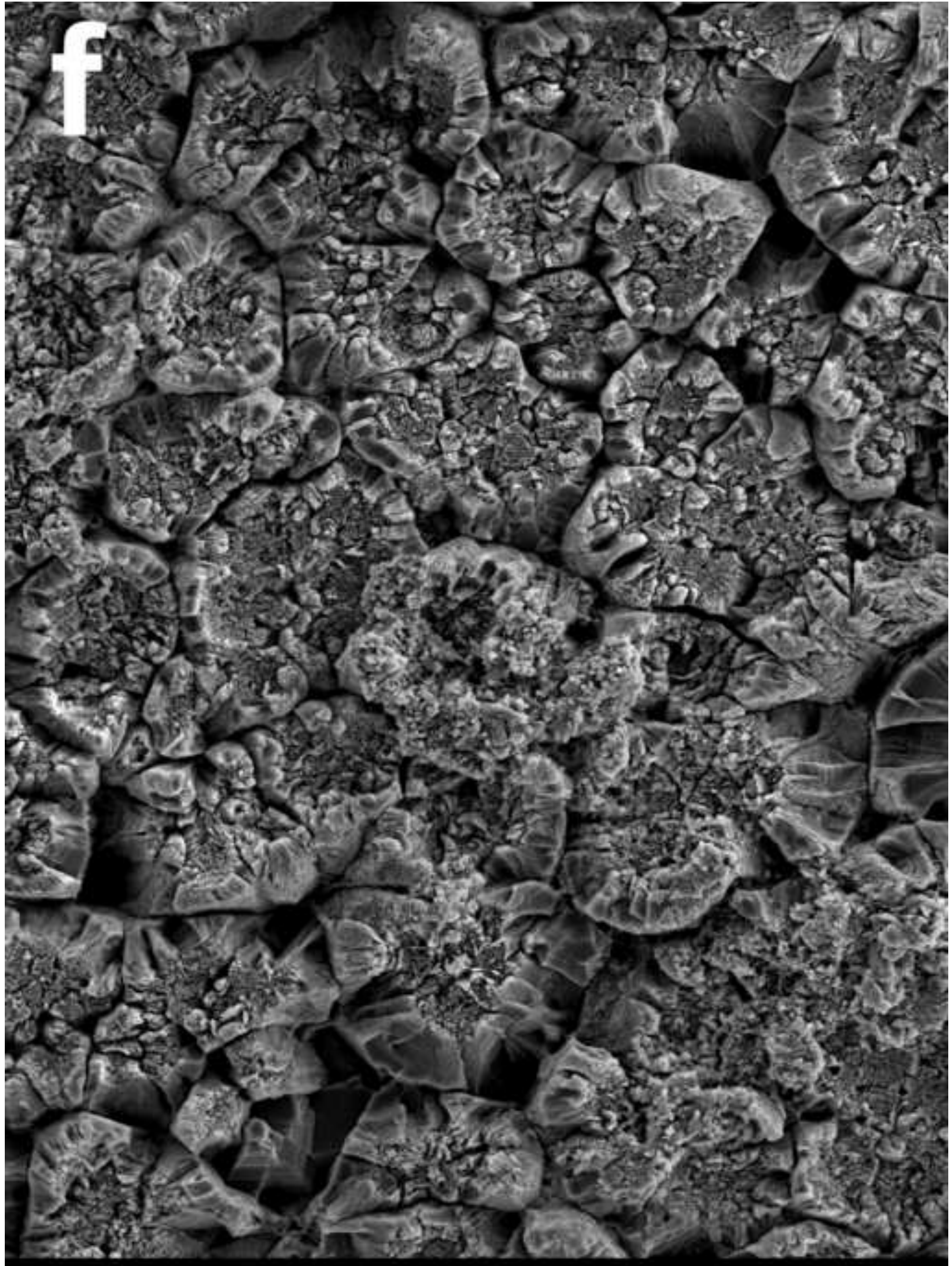

Bag 440

$80 \mu \mathrm{m} 500 \mathrm{X}$ 